\title{
Electronic Safety Resource Tools - Supporting Hydrogen and Fuel Cell Commercialization
}

\author{
NF Barilo
}

September 2014

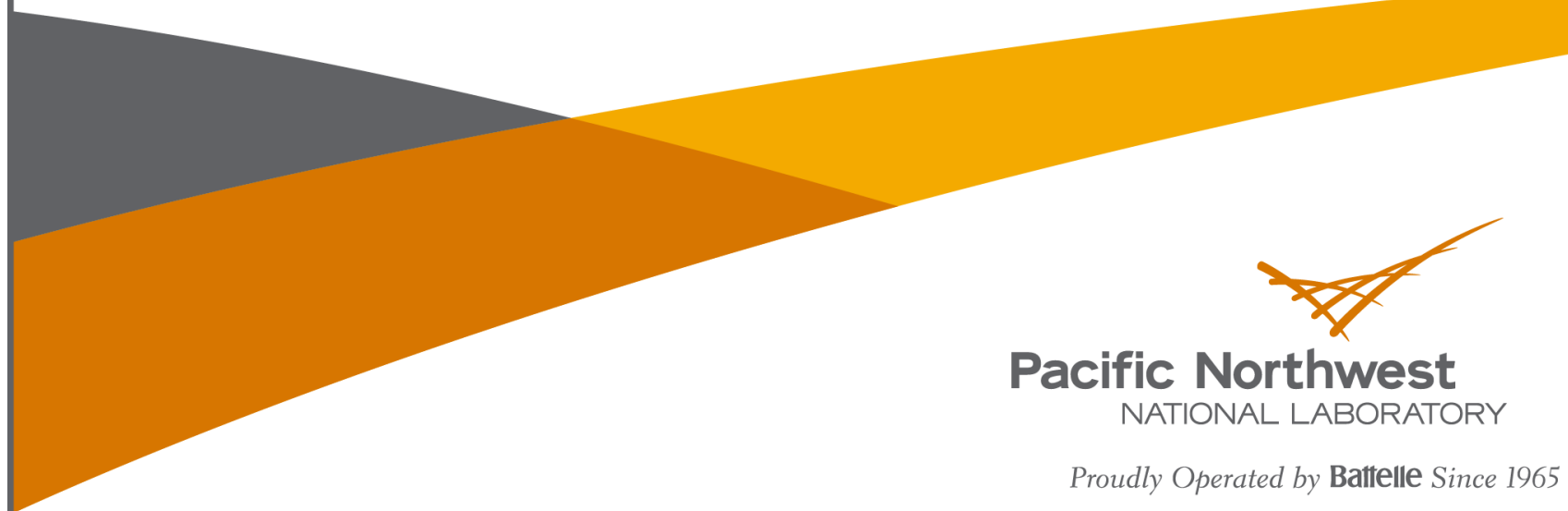




\title{
DISCLAIMER
}

This report was prepared as an account of work sponsored by an agency of the United States Government. Neither the United States Government nor any agency thereof, nor Battelle Memorial Institute, nor any of their employees, makes any warranty, express or implied, or assumes any legal liability or responsibility for the accuracy, completeness, or usefulness of any information, apparatus, product, or process disclosed, or represents that its use would not infringe privately owned rights. Reference herein to any specific commercial product, process, or service by trade name, trademark, manufacturer, or otherwise does not necessarily constitute or imply its endorsement, recommendation, or favoring by the United States Government or any agency thereof, or Battelle Memorial Institute. The views and opinions of authors expressed herein do not necessarily state or reflect those of the United States Government or any agency thereof.

\author{
PACIFIC NORTHWEST NATIONAL LABORATORY \\ operated by \\ BATTELLE \\ for the \\ UNITED STATES DEPARTMENT OF ENERGY \\ under Contract DE-AC05-76RL01830 \\ Printed in the United States of America \\ Available to DOE and DOE contractors from the \\ Office of Scientific and Technical Information, \\ P.O. Box 62, Oak Ridge, TN 37831-0062; \\ ph: (865) 576-8401 \\ fax: (865) 576-5728 \\ email: reports@adonis.osti.gov
}

Available to the public from the National Technical Information Service

5301 Shawnee Rd., Alexandria, VA 22312

ph: (800) 553-NTIS (6847)

email: orders@ntis.gov <http://www.ntis.gov/about/form.aspx>

Online ordering: http://www.ntis.gov 
PNNL-23704

Electronic Safety Resource Tools - Supporting Hydrogen and Fuel Cell Commercialization

N Barilo

September 2014

Prepared for

the U.S. Department of Energy

under Contract DE-AC05-76RL01830

Pacific Northwest National Laboratory

Richland, Washington 99352 


\section{Executive Summary}

The Pacific Northwest National Laboratory (PNNL) Hydrogen Safety Program conducted a planning session in Los Angeles, CA on April 1, 2014 to consider what electronic safety tools would significantly benefit the next phase of hydrogen and fuel cell commercialization. A diverse, 20-person team led by an experienced facilitator considered the question as it applied to the eight most relevant user groups. The results and subsequent evaluation activities revealed several possible resource tools that could greatly benefit users.

The tool identified as having the greatest potential for impact is a hydrogen safety portal, which can be the central location for integrating and disseminating safety information (including most of the tools identified in this report). Such a tool can provide credible and reliable information from a trustworthy source. Other impactful tools identified include a codes and standards wizard to guide users through a series of questions relating to application and specific features of the requirements; a scenario-based virtual reality training for first responders; peer networking tools to bring users from focused groups together to discuss and collaborate on hydrogen safety issues; and a tool for training inspectors. Table ES.1 provides results of the planning session, including proposed new tools and changes to existing tools.

Table ES.1. Results of the Planning Session

\begin{tabular}{|c|c|c|}
\hline Priority & New Tools & Update of Existing Tools \\
\hline \multirow[t]{11}{*}{ High } & Hydrogen safety portal & $\begin{array}{l}\text { Update URL and name for Hydrogen Incident and } \\
\text { Lessons Learned Database }\end{array}$ \\
\hline & Codes and standards wizard & $\begin{array}{l}\text { Update training content from Adobe Flash to HTML5 } \\
\text { - Intro to Hydrogen Safety for First Responders } \\
\text { - Intro to Hydrogen for Code Officials } \\
\text { - Hydrogen Safety Training for Researchers }\end{array}$ \\
\hline & Scenario-based training for first responders & Update content of Permitting Hydrogen Faculties \\
\hline & Peer networking tools & Update Hydrogen Safety Bibliographic Database \\
\hline & Training for inspectors & $\begin{array}{l}\text { Update Regulation, Codes, and Standards Template } \\
\text { for national application }\end{array}$ \\
\hline & Modeling/QRA tools $^{(a)}$ & $\begin{array}{l}\text { Simplify Technical Reference for Hydrogen } \\
\text { Compatibility of Materials for non-expert use }\end{array}$ \\
\hline & Risk assessment tools $^{(a)}$ & $\begin{array}{l}\text { Hydrogen Analysis Resource Center (HARC): } \\
\text { Hydrogen Conversion Calculator }\end{array}$ \\
\hline & Third party certification guide ${ }^{(a)}$ & $\begin{array}{l}\text { Evaluate HARC: Basic Hydrogen Properties to } \\
\text { include additional content }\end{array}$ \\
\hline & Equipment and project performance data & Update Hydrogen Safety Snapshot \\
\hline & Response hotline & $\begin{array}{l}\text { Convert Hydrogen Safety Best Practices to a database } \\
\text { driven format }\end{array}$ \\
\hline & $\begin{array}{l}\text { Training for maintenance and operations } \\
\text { personnel }\end{array}$ & \\
\hline Low & General safety tools & \\
\hline
\end{tabular}

(a) Tools already under development. These will need to be integrated with a web based resource or the hydrogen safety portal. 
Ultimately, the new tools in Table ES.1 could help bring safety information to a broader audience in a more relevant manner. These tools can help remove barriers to project development and approval, and support a safer implementation of a hydrogen infrastructure. The U.S. Department of Energy, H2USA, and other interested parties should consider collaborations to develop and promote these tools. 


\section{Acronyms and Abbreviations}

$\begin{array}{ll}\text { AHJ } & \text { authority having jurisdiction } \\ \text { DOE } & \text { U.S. Department of Energy } \\ \text { ESRT } & \text { electronic safety resource tool } \\ \text { O\&M } & \text { operations and maintenance } \\ \text { OEM } & \text { original equipment manufacturer } \\ \text { PNNL } & \text { Pacific Northwest National Laboratory } \\ \text { QRA } & \text { quality risk assessment }\end{array}$




\section{Contents}

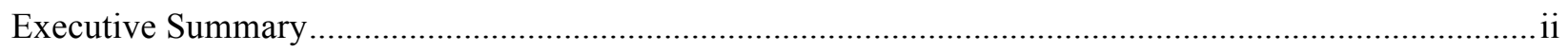

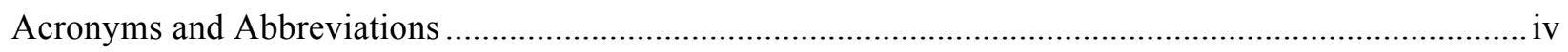

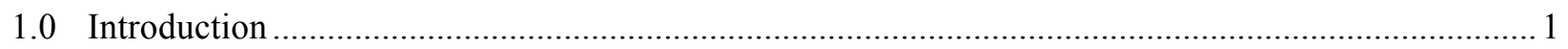

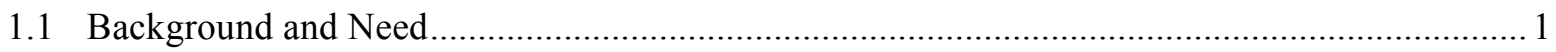

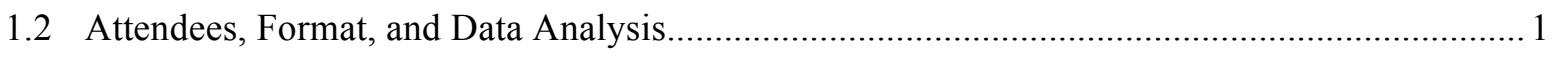

1.2.1 Agreement on User Group Designations ............................................................. 1

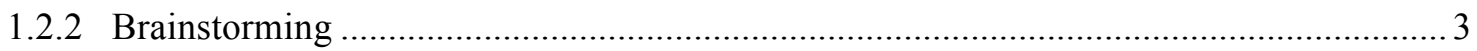

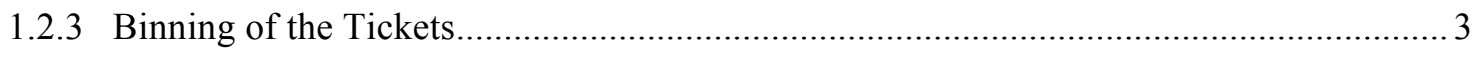

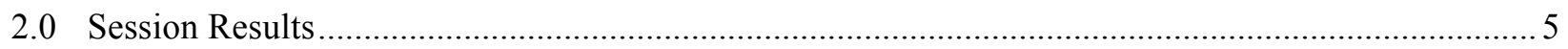

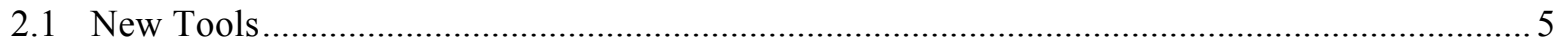

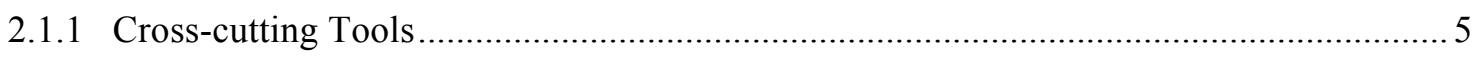

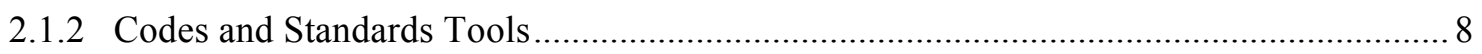

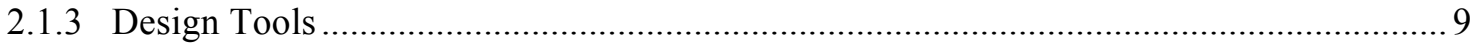

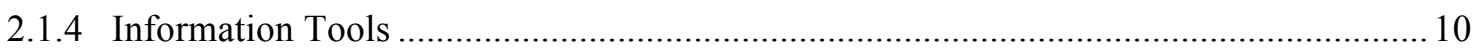

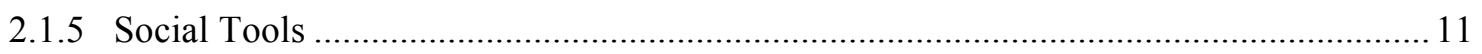

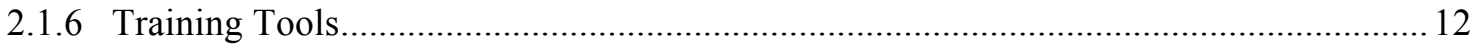

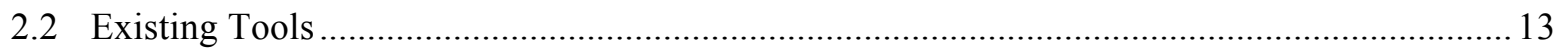

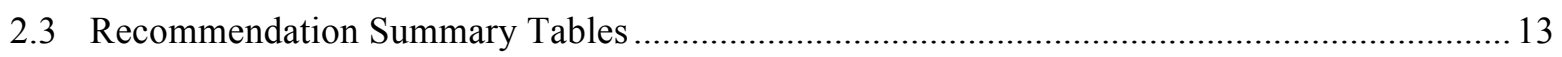

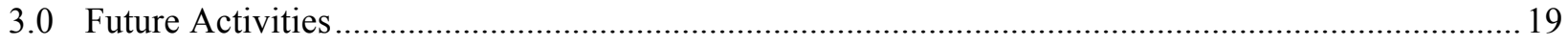

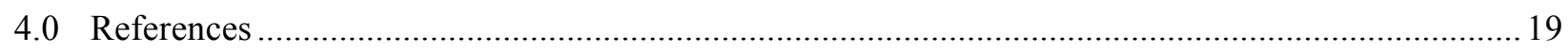

Appendix A Existing Hydrogen and Fuel Cell Safety Electronic Resources......................................... A.1

Appendix B Electronic Safety Resources Planning Session Attendees ................................................. B.1

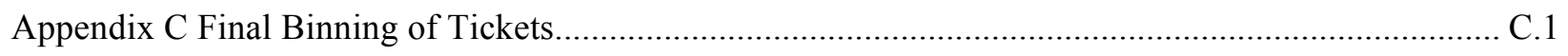

Appendix D Affected User Groups for New Functional Tools............................................................ D.1

Appendix E Affected User Groups for Existing Electronic Safety Resource Tools (DOE \& Non-

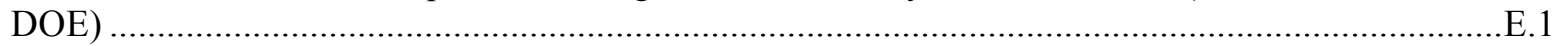

Appendix F Tickets Associated with Existing Tools .................................................................... 


\section{Figures}

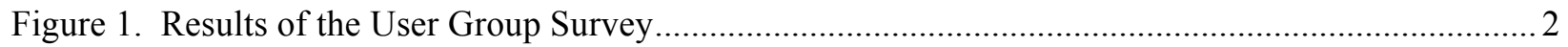

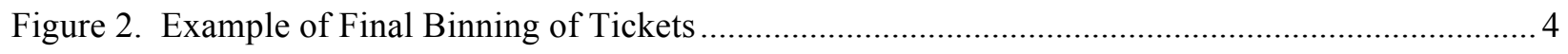

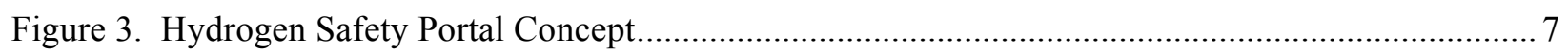

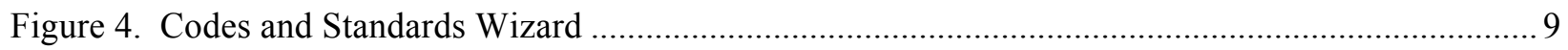

\section{Tables}

Table 1. Benefits and Potential Features of a Hydrogen Safety Portal ................................................... 6

Table 2. Recommendations for Implementation of New Tools .......................................................... 14

Table 3. Recommendations for Existing Electronic Safety Resource Tools........................................... 16 


\subsection{Introduction}

The Pacific Northwest National Laboratory (PNNL) Hydrogen Safety Program conducted a planning session in Los Angeles, CA on April 1, 2014 to consider what electronic safety tools would significantly benefit the next phase of hydrogen and fuel cell commercialization. A diverse, 20-person team led by an experienced facilitator considered the question as it applied to the eight most relevant user groups. This report describes the results of the meeting and subsequent evaluation activities, including descriptions of several possible resource tools that could greatly benefit users.

\subsection{Background and Need}

One goal of the U.S. Department of Energy (DOE) Fuel Cell Technologies Office is to provide comprehensive safety data, information, and knowledge resources to a broad range of stakeholders. As stated in the Fuel Cell Technologies Office Multi-Year Research, Development, and Demonstration Plan (DOE 2013), "the widespread availability and communication of safety-related information are crucial to ensure the safe operation of future hydrogen and fuel cell technology systems. The entire hydrogen community benefits if hydrogen safety-related knowledge is openly and broadly shared." While a variety of electronic safety resource tools (ESRTs) are available to support this goal (see Appendix A), now is an appropriate time to ask if we have the right tools to support this next phase toward hydrogen and fuel cell commercialization.

To answer that question and best leverage DOE's investment in these tools, a planning session was held to support the development of an overall electronic resource strategy so that key audiences get the information they need in the most efficient manner. The session brought together individuals and organizations responsible for the existing resources and additional stakeholders to identify redundancy in tools, needs to update content, and gaps that need to be addressed to meet the needs of our target audiences.

\subsection{Attendees, Format, and Data Analysis}

Twenty individuals representing a variety of user groups and owners of the existing resource tools participated in the meeting, which held was at the City of Santa Fe Springs Department of FireRescue, located southeast of Los Angeles, CA (a list of attendees can be found in Appendix B). The location was chosen due to its proximity to stakeholders, authorities having jurisdiction (AHJs), project proponents, and original equipment manufacturers (OEMs) with experience in recent hydrogen fueling station and deployment activities.

\subsubsection{Agreement on User Group Designations}

Prior to the planning session, potential user groups of ESRTs were identified. This helped focus the planning session and ensure that the 
results could be manageable and useful in understanding gaps and future needs. Initially, seven user groups were identified:

- Authorities Having Jurisdiction (AHJ) - includes code officials, inspectors, and those have approval authority for a project

- First Responders/Second Responders (FR/SR) - fire departments, law enforcement, emergency medical personnel, and secondary responders such as wrecking crews

- Operations \& Maintenance $(\mathrm{OM})$ - those responsible for operating and maintaining equipment after it is in service

- The Public (PUB) - general public

- Project Proponents (PP) - gas providers, engineers, architects, etc.

- Research \& Development (RD) - individuals responsible for development activities

- Stakeholders (STK) - investors and those interested in the outcome of a project

Attendees were asked to rank user groups before the meeting to verify that the right groups were included and assign their priority. The results (Figure 1) show that the AHJ and FR groups were felt to have the greatest need.

\begin{tabular}{|c|c|c|c|c|c|c|c|c|c|c|}
\hline & $\nabla$ & $\nabla$ & $\nabla$ & 3 & $\nabla$ & $\nabla$ & 6 & 7 & Total $\vee$ & $\begin{array}{l}\text { Average } \\
\text { Ranking }\end{array}$ \\
\hline$\nabla$ & $\begin{array}{l}\text { AHJ - } \\
\text { Authorities } \\
\text { having } \\
\text { jurisdiction }\end{array}$ & $\begin{array}{r}18.18 \% \\
2\end{array}$ & $\begin{array}{r}63.64 \% \\
7\end{array}$ & $\begin{array}{r}0.00 \% \\
0\end{array}$ & $\begin{array}{r}9.09 \% \\
1\end{array}$ & $\begin{array}{r}9.09 \% \\
1\end{array}$ & $\begin{array}{r}0.00 \% \\
0\end{array}$ & $\begin{array}{r}0.00 \% \\
0\end{array}$ & 11 & 5.73 \\
\hline$\nabla$ & $\begin{array}{l}\text { FR - First } \\
\text { responders } \\
\text { (fire, law } \\
\text { enforcement, } \\
\text { and } \\
\text { emergency } \\
\text { medical } \\
\text { personnel) }\end{array}$ & $\begin{array}{r}27.27 \% \\
3\end{array}$ & $\begin{array}{r}27.27 \% \\
3\end{array}$ & $\begin{array}{r}36.36 \% \\
4\end{array}$ & $\begin{array}{r}0.00 \% \\
0\end{array}$ & $\begin{array}{r}9.09 \% \\
1\end{array}$ & $\begin{array}{r}0.00 \% \\
0\end{array}$ & $\begin{array}{r}0.00 \% \\
0\end{array}$ & 11 & 5.64 \\
\hline$\nabla$ & $\begin{array}{l}\text { OM - } \\
\text { Operations } \\
\text { and } \\
\text { maintenance } \\
\text { personnel }\end{array}$ & $\begin{array}{r}18.18 \% \\
2\end{array}$ & $\begin{array}{r}0.00 \% \\
0\end{array}$ & $\begin{array}{r}18.18 \% \\
2\end{array}$ & $\begin{array}{r}27.27 \% \\
3\end{array}$ & $\begin{array}{r}9.09 \% \\
1\end{array}$ & $\begin{array}{r}18.18 \% \\
2\end{array}$ & $\begin{array}{r}9.09 \% \\
1\end{array}$ & 11 & 4.00 \\
\hline$\nabla$ & $\begin{array}{l}\text { PB - The } \\
\text { public }\end{array}$ & $\begin{array}{r}0.00 \% \\
0\end{array}$ & $\begin{array}{r}0.00 \% \\
0\end{array}$ & $\begin{array}{r}0.00 \% \\
0\end{array}$ & $\begin{array}{r}9.09 \% \\
1\end{array}$ & $\begin{array}{r}9.09 \% \\
1\end{array}$ & $\begin{array}{r}36.36 \% \\
4\end{array}$ & $\begin{array}{r}45.45 \% \\
5\end{array}$ & 11 & 1.82 \\
\hline$\nabla$ & $\begin{array}{l}\text { PP - Project } \\
\text { proponents }\end{array}$ & $\begin{array}{r}9.09 \% \\
1\end{array}$ & $\begin{array}{r}9.09 \% \\
1\end{array}$ & $\begin{array}{r}18.18 \% \\
2\end{array}$ & $\begin{array}{r}18.18 \% \\
2\end{array}$ & $\begin{array}{r}18.18 \% \\
2\end{array}$ & $\begin{array}{r}9.09 \% \\
1\end{array}$ & $\begin{array}{r}18.18 \% \\
2\end{array}$ & 11 & 3.73 \\
\hline$\nabla$ & $\begin{array}{l}\text { RD - } \\
\text { Researchers, } \\
\text { scientists, } \\
\text { engineers }\end{array}$ & $\begin{array}{r}9.09 \% \\
1\end{array}$ & $\begin{array}{r}0.00 \% \\
0\end{array}$ & $\begin{array}{r}18.18 \% \\
2\end{array}$ & $\begin{array}{r}18.18 \% \\
2\end{array}$ & $\begin{array}{r}36.36 \% \\
4\end{array}$ & $\begin{array}{r}18.18 \% \\
2\end{array}$ & $\begin{array}{r}0.00 \% \\
0\end{array}$ & 11 & 3.73 \\
\hline$\nabla$ & $\begin{array}{l}\text { STK - } \\
\text { Stakeholders } \\
\text { having an } \\
\text { interest in } \\
\text { the } \\
\text { successful } \\
\text { completion } \\
\text { of a project }\end{array}$ & $\begin{array}{r}18.18 \% \\
2\end{array}$ & $\begin{array}{r}0.00 \% \\
0\end{array}$ & $\begin{array}{r}9.09 \% \\
1\end{array}$ & $\begin{array}{r}18.18 \% \\
2\end{array}$ & $\begin{array}{r}9.09 \% \\
1\end{array}$ & $\begin{array}{r}18.18 \% \\
2\end{array}$ & $\begin{array}{r}27.27 \% \\
3\end{array}$ & 11 & 3.36 \\
\hline
\end{tabular}

Figure 1. Ranking of the User Group 
An eighth group, Insurers and Risk Managers (INS), was added to the above list at the start of the meeting on April 1 as a result of input from attendees of the session. The Stakeholder group was also renamed Investors (INV) at this time.

\subsubsection{Brainstorming}

The brainstorming portion of the meeting focused on soliciting unconstrained ideas (referred to as "tickets") from attendees for each user group identified in section 1.2.1. The activity yielded 136 ideas, or tickets. These tickets were assigned to a specific user group or multiple user groups where appropriate. Next, tickets with common themes were organized by session participants into stories (a term to describe what an end user or user of a system does or needs to do as part of his or her job function, based on themes of individual tickets). Stories were only developed for the four highest priority user groups (identified in Figure 1) due to time constraints. Stories for the other four user groups were analyzed by Pacific Northwest National Laboratory (PNNL) in the weeks following the meeting.

\subsubsection{Binning of the Tickets}

The tickets were entered into a database and categorized based on their initial user group assignment. A few tickets were not included with user group information and were assigned an "UNGRP" designation to track the tickets while maintaining integrity of the meeting results.

The tickets were then binned and evaluated for commonality and purpose. The evaluation was a multi-step process that began with tickets being arranged by user group. During the first binning, tickets were arranged into the following categories within each user group:

- Distance training

- Hands-on training

- Codes and standards

- Design/risk

- Certification

- On scene

- Interactive

- Networking

- General information

- Uncategorized

During the next phase, tickets with a common category were moved from user groups and placed together (i.e., into a "category" bin). The final phase focused on arranging tickets within these categories together based on a common functionality (tools). Twenty-two potential tools were identified. These tools are not necessarily meant to be unique products but represent a focus on common functionality. An example of the final binning can be seen in Figure 2. All tickets and their grouped functionality can be found in Appendix C. 


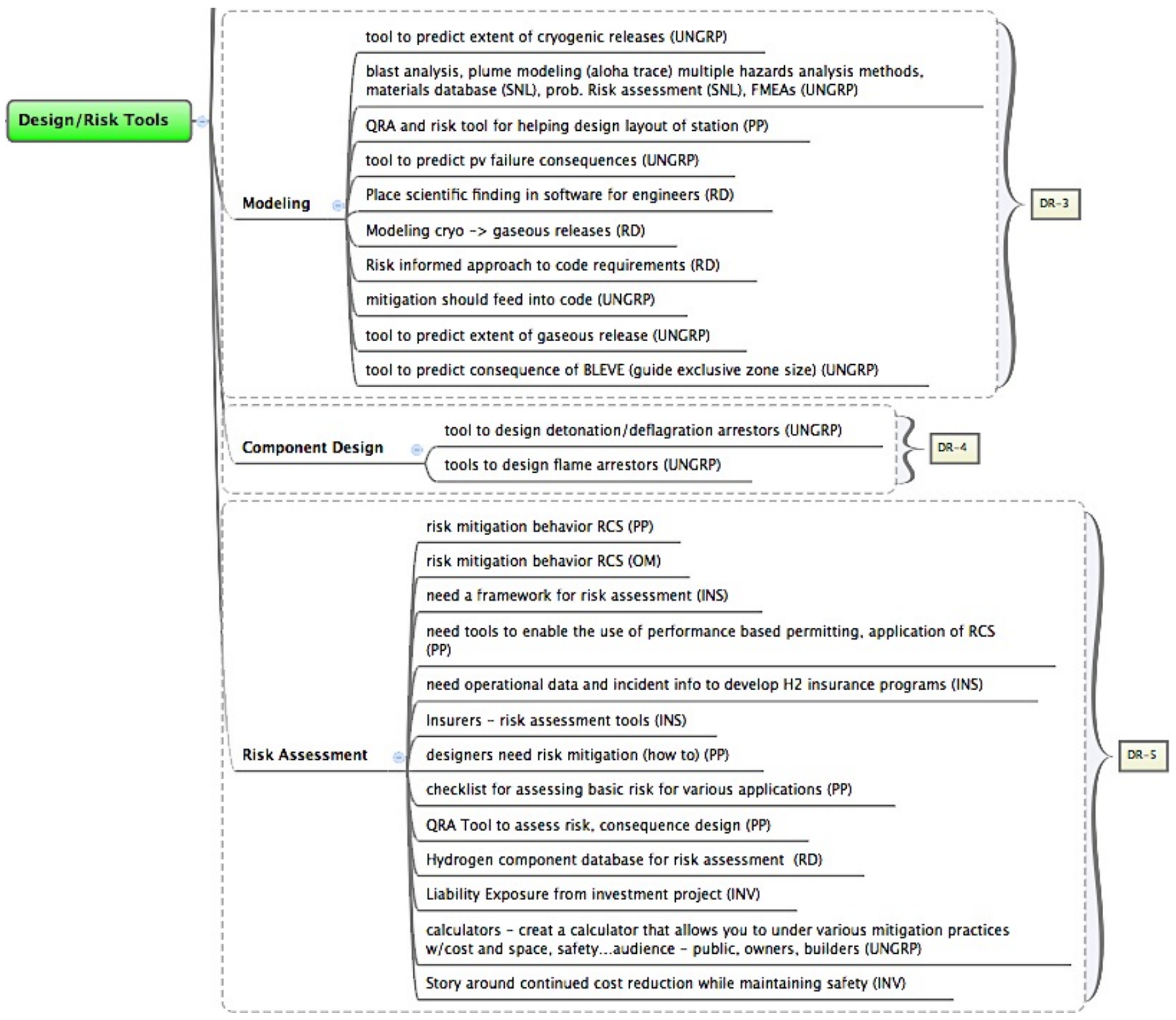

Figure 2. Example of Final Binning of Tickets 


\subsection{Session Results}

The planning session revealed areas where the user groups could benefit from a new approach to safety knowledge resources (see Appendix D). The following sections discuss new resources based on meeting results as well as the existing tools. Recommendations for implementing new tools and updating existing tools are also provided.

\subsection{New Tools}

The new tools were divided into six groups:

- Cross-cutting tools

- Codes and standards tools

- Design tools (modeling tools, risk assessment tools, design tools, etc.)

- Information tools (general safety, vehicle information, etc.)

- Social tools (networking and hotlines)

- Training tools

The recommendations for implementing new tools are summarized in section 2.3. The recommendations are subdivided by potential impact based on overall value and need. High impact items are considered those that have immediate benefit and/or benefit across a large number of user groups. Medium impact is designated for items recognized as having substantial impact but at a high cost and time needed for development. Low impact is designated for an item that is more directed at niche needs. Items that have very low ranking numbers or that do not fit well as a DOE ESRT are identified in Table 1 as not requiring development. These tools could be developed by other organizations as needed. Finally, the planning session confirmed the need for three tools already under development.

\subsubsection{Cross-cutting Tools}

\section{Hydrogen Safety Portal - A Nexus for Safety Information and Professional Networking (GI-1)}

Participants in the planning session suggested that a hydrogen safety web portal, serving as a single source for credible and reliable safety information, would be very beneficial. DOE has a variety of electronic hydrogen safety resources and tools that are spread across government, national laboratory, and support organization's web sites. These are sometimes difficult to navigate to (via Google search) and lack a consistent look and feel. Others are outdated or use outdated technology. A portal could integrate these existing resources to facilitate accessibility (and display) from a single, trustworthy source, thereby increasing their visibility and value. 


\section{The Value of Combining Resources}

The value of a network (or service/site, e.g., Twitter) is proportional to the square of the number of users (Metcalfe's law, http://en.wikipedia.org/wiki/Metcalfe\%27s law). Aggregating information and tools into a central location aggregates its users and increases the value of each application by reducing effort (one-stop-shopping) and increasing the population of potential users the same way a mall does for its stores' customers. A customer on the way to store C must first pass stores A and B. Customers may not even know store $\mathrm{B}$ exists until they walk past on the way to store $\mathrm{C}$ (their intended purpose). In addition to hosting existing tools, the portal could contain wikis, discussion forums, knowledge bases, FAQs, searchable articles, and a variety of other tools designed to facilitate peer networking and the development of a safety community.

The viral or exponential growth possible as the number of users is increased is the way social networks tend to grow (users tend to invite others) (Reed's law, http://en.wikipedia.org/wiki/ Reed $\% 27 \mathrm{~s}$ law). Increased value through aggregated tools and information combined with the increase in users has the potential for rapid growth much more than individual, disparate, decentralized strategies do. This approach also provides the opportunity to reduce support costs by leveraging one infrastructure, technology, etc.

Table 1 summarizes potential benefits and features. A concept of a portal that includes these benefits and features is provided in Figure 3.

Potential Impact: High

Table 1. Benefits and Potential Features of a Hydrogen Safety Portal

\begin{tabular}{|c|c|}
\hline Centralized Location & $\begin{array}{l}\text { Organizing current hydrogen resources into one robust location - } \\
\text { including more than } 20 \text { existing tools and capability for easily adding } \\
\text { future content }\end{array}$ \\
\hline Focused Content & Tailored to the specialized needs of hydrogen user groups \\
\hline Customizable Interface & Allowing content to display based on the user's role or interests \\
\hline Responsive Design & $\begin{array}{l}\text { Enabling hydrogen safety work across both desktop and mobile devices } \\
\text { (eliminating the need for a separate IOS app) }\end{array}$ \\
\hline Trusted Communities & $\begin{array}{l}\text { Fostered through social networking around hydrogen subject matter } \\
\text { expertise }\end{array}$ \\
\hline Expandable Format & Built with frequently requested future feature sets in mind \\
\hline
\end{tabular}




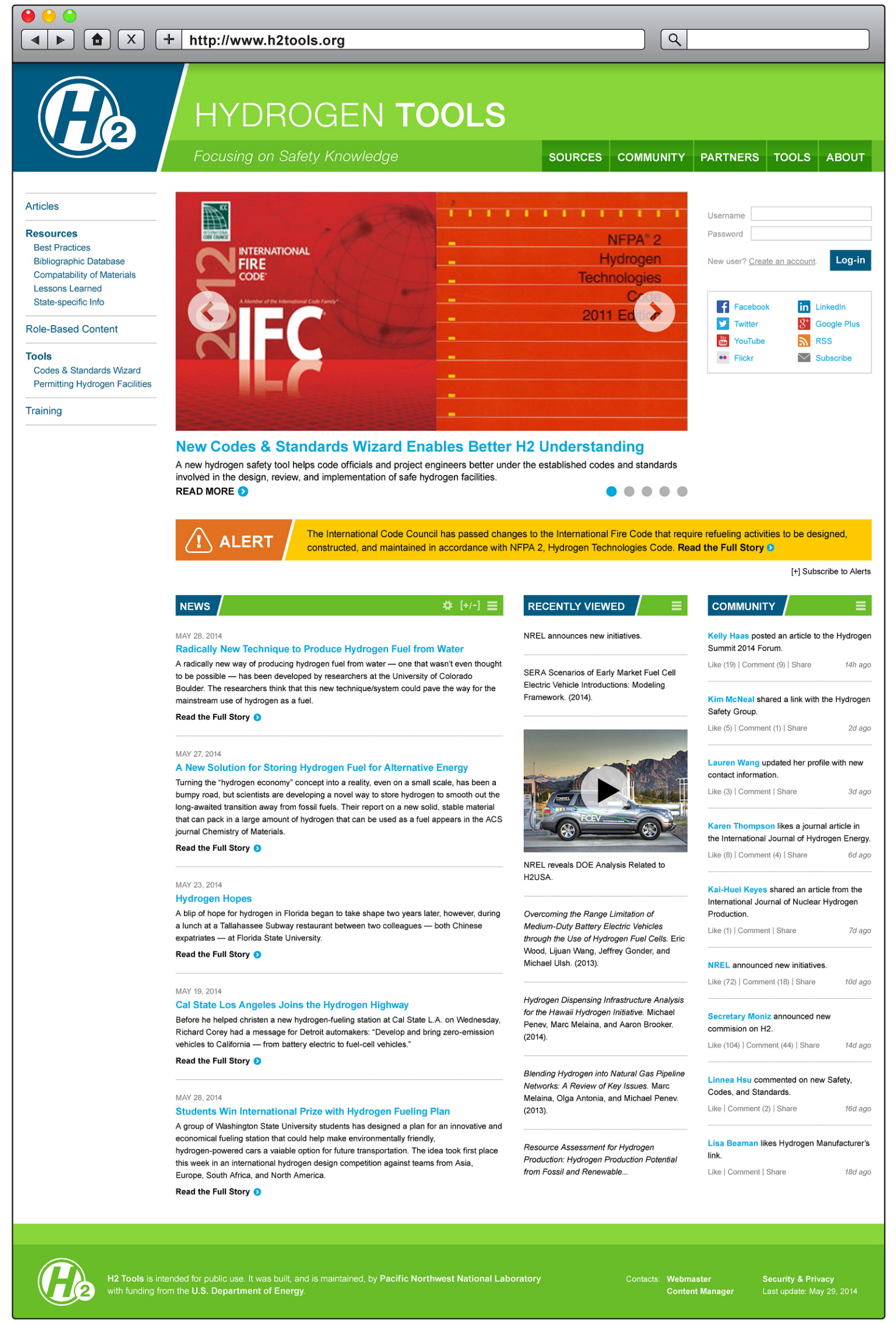

Figure 3. Hydrogen Safety Portal Concept 


\title{
2.1.2 Codes and Standards Tools
}

\author{
Codes and Standards Wizard/Guide (CS-1)
}

There are many codes, standards, regulations and other criteria (ICC, NFPA, ASTM, ASME, UL, CSA, etc.) that govern the design, construction, installation, commissioning, operations and maintenance of hydrogen and fuel cell technologies. It is extremely difficult for an AHJ or project proponent to understand all applicable criteria and then determine which provisions apply to the installation and its component parts. Without experienced personnel, the best case scenario is simply lost time in getting an installation approved and permitted and the worst case is finding out too late that substantial revisions are required.

The topic of codes and standards was the most ticketed and discussed idea at the planning session and highlighted the need for a resource tool. Session participants shared a need for an overview of requirements; simplified code application; an outline of code requirements; a list of applicable codes and standards; help to understand codes and standards and applicable requirements. There are a few code and standard electronic resources currently available, such as http://www.fuelcellstandards.com/ and the National Renewable Energy Laboratory's Regulations, Codes, and Standards (RCS) Template for California Hydrogen Dispensing Stations. However, these may not meet the deeper need for a more systematic and intuitive tool.

The concept of a drill-down, question-based tool (similar to Intuit's TurboTax ${ }^{\circledR}$ tool) surfaced as being an ideal solution. Such a tool would guide the user through a series of questions relating to application, topics, and subtopics to help them identify the applicable requirements in a timely manner. More technically speaking, this could be an interactive relational database-driven web app based on codes, standards, and regulations applicable to hydrogen and fuel cell technologies. In addition to identifying applicable requirements, it is recommended that programmers consult with the Building Smart Alliance at the National Institute of Building Sciences to explore how the database could be applied to Building Information Modeling (BIM) related software. Such an effort could facilitate the creation of plans and specifications and automatic checking of those plans and specifications for compliance with applicable building regulations as represented by the database. This approach is being used by both technology proponents and regulators to help ensure a common and accurate understanding of the building regulations applicable to a proposed installation, more timely review and approval of what is proposed, and more timely completion and operation of the installation.

Integrating this tool with the hydrogen safety portal discussed in the previous section would open up significant opportunities to bring additional information to help the user understand how to apply the requirements. For example, once the user is systematically led through the wizard to a particular set of requirements, the portal could also display information such as best practices (from h2bestpractices.org), related lessons learned, instructional videos and wikis, and community discussion or feedback on related topics. A flowchart of how this might work is provided in Figure 4.

Potential Impact: High 


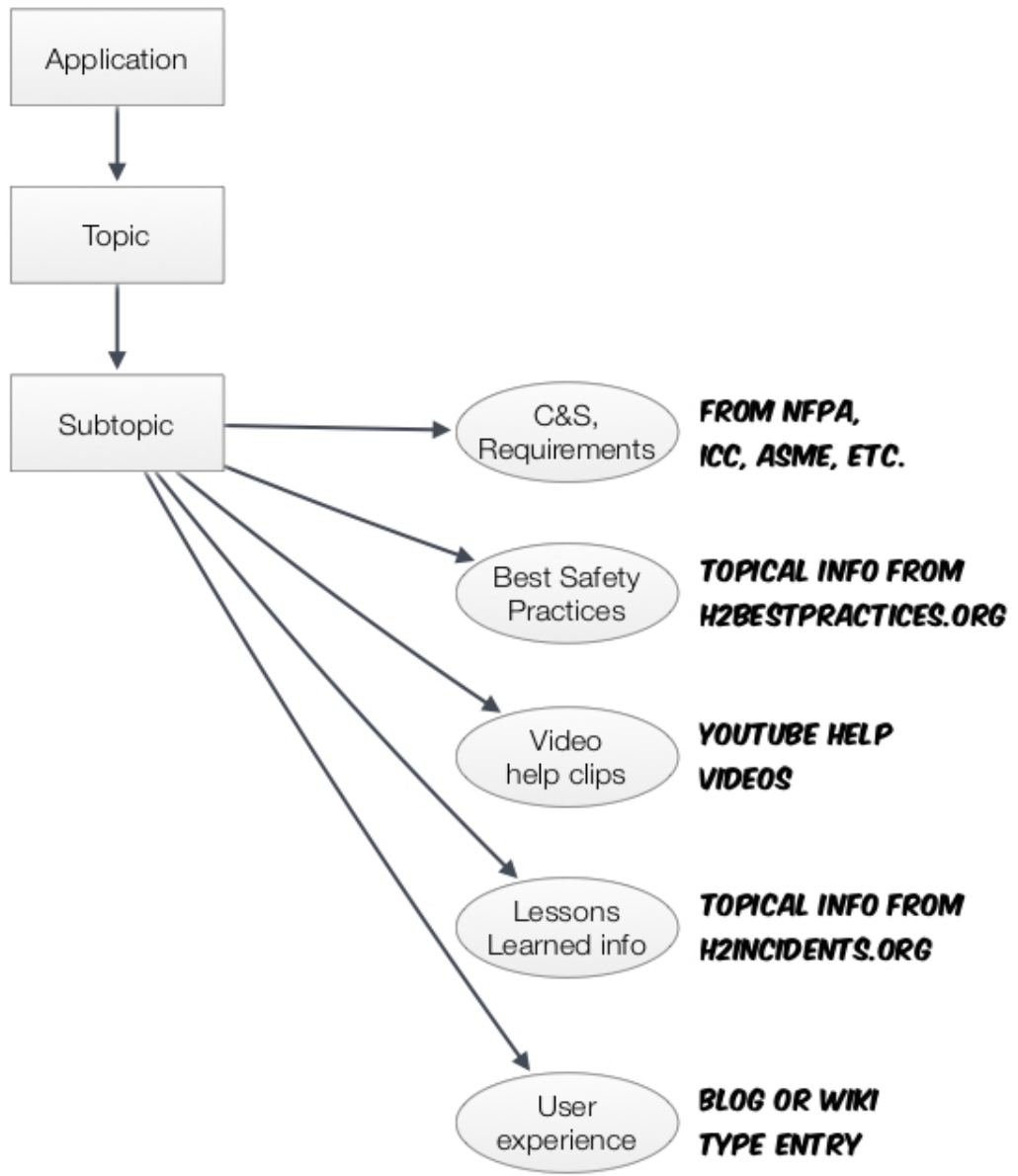

Figure 4. Codes and Standards Wizard

\subsubsection{Design Tools}

Design tools discussed during the planning session include the following:

- Modeling/quality risk assessment (QRA) tools

- Risk assessment tools

- Station location and design tools

- Equipment and project performance data

- Third party certification guide

These tools and data should be made readily available through an online resource such as the hydrogen safety portal.

Modeling/QRA Tools (DR-3)

This includes modeling tools to predict consequences of cryogenic releases, pressure valve failure, cryogenic to gas releases, gaseous releases, BLEVEs, etc., to support fueling station designs and risk 
informed changes to regulation, codes, and standards. These tools are already under development by Sandia National Laboratories.

Potential Impact: Already being developed

$\underline{\text { Risk Assessment Tools (DR-5) }}$

This includes tools to enable risk assessments and provide options for risk mitigation and support performance-based analysis. It could include checklists for basic risk; component databases; calculators; and cost-benefit features. These tools are already under development by Sandia National Laboratories.

Potential Impact: Already being developed

$\underline{\text { Station Location and Design Tools (DR-1) }}$

This includes design tools to help identify station locations (mapping), options for station configurations, standardized plan formats, and obstacles to project deployments. The evaluation group (April 2 and Hydrogen Safety Panel members) felt this tool would not provide significant impact and that station providers have enough existing resources to address this need.

Potential Impact: No further effort by DOE is needed.

Equipment and Project Performance Data (DR-2)

This includes data on equipment and project performance including failure rate data, mean time between failures, incident data, real-time system performance, and "denominator" information for frequency of incidents. While some of this information is available through the NREL secure database, much more work is needed in this area. These tools could have a significant impact but will take much industry support and time to develop.

Potential Impact: Medium

\section{Third Party Certification Guide (CI-1)}

A guide for project certification by third party is needed and should be based on a tool/methodology that the AHJ can trust, and may include a component certification checklist. This activity is similar to work being performed by the Hydrogen Safety Panel task group on certification. That work is expected to produce a document that could be made available electronically in support of this effort.

Potential Impact: Already being developed

\subsubsection{Information Tools}

Four types of information tools were identified during the analysis of the tickets and are discussed in this section:

- General safety tools

- Vehicle and equipment safety information 
- On-scene vehicle information

- List of listed or approved equipment

General Safety Tools (GI-4)

These tools include general safety information on hydrogen properties and behavior. Some general safety tools already exist, including properties and conversion calculators. Other areas, such as answers to general questions, pressure safety, flame arrestors, vent systems, relief devices, provide opportunity for further development and should be developed as needs arise. The tools could be included with other tools and/or made available through an online resource such as the hydrogen safety portal.

Potential Impact: Low

Vehicle and Equipment Safety Information (GI-3)

This includes vehicle and equipment information covering general information, safety features, safe usage parameters, recall notices, and so forth. This information should be developed and deployed by OEMs. H2USA could help ensure the necessary information is made available.

Potential Impact: No further effort by DOE is needed.

On-scene Vehicle Information (OS-1)

These tools would provide critical safety information to firefighters and secondary responders (tow and wrecking) when responding to an event and would include details based on vehicle identification number scanning. OEMs should work with secondary responders to identify needs and develop the appropriate tools.

Potential Impact: No further effort by DOE is needed.

$\underline{\text { Tool for Listed or Approved Equipment (CI-2) }}$

This tool would provide information for listed/approved equipment and systems to support review and approval of designs. While there is an obvious need for this information, very few listed components and systems are available due to the relative immaturity of the industry. When listed equipment becomes available, the testing laboratories would be the best resource to make the listing databases available. Until then, pursuing the third party certification guide (CI-1) is a good alternative.

Potential Impact: No further effort by DOE is needed.

\subsubsection{Social Tools}

\section{Peer Networking (NW-1/NW-2/NW-3)}

This includes tools to help establish connections and discussions among peers within the following user groups: AHJs, inspectors, researchers, OEMs, and project proponents. Interactions with various user groups, feedback at the planning session, and general industry social movement suggest great value in 
these types of tools. Connecting inspectors and code officials also has the potential to reduce delays in project approval due to lack of experience. These tools could be standalone products but would likely be more useful if they were integrated with other electronic safety resources and the hydrogen safety portal.

Potential Impact: High

$\underline{\text { Response Hotline (IA-2) }}$

Session attendees suggested that a hotline be developed for responding to incidents and special issues. This could be a standalone phone number or be combined with various social media tools.

Potential Impact: Medium

\subsubsection{Training Tools}

Inspectors (TR-2)

A tool to train code official inspectors in support of permitting and approval of hydrogen facilities was deemed valuable by session attendees. This tool could provide an opportunity to help AHJ reduce approval and permitting times. It could be implemented through short instructional videos incorporated into the portal and codes and standards wizard.

Potential Impact: High

Operations and Maintenance Personnel (TR-1)

Operations and maintenance personnel could benefit from training on hazards and operating equipment that can provide certification. This tool could help reduce the number and severity of potential events as O\&M personnel are unfamiliar with the hazards of working with hydrogen.

Potential Impact: Medium

Scenario-Based Training for First Responders (NN-1)

First responders can greatly benefit from hands-on and scenario-based training. Hands-on training currently exists (through PNNL) but its use is limited due to expense (moving props and equipment to training locations) and the limited number of scenarios available for participants (and only vehicle scenarios). Recent collaborations with the European based HyResponse program offer another opportunity in the form of an electronic virtual reality training tool that will allow for an unlimited number and types of scenarios that can be developed for class participants and support remote class participation. Such a tool could build on the current successes of the PNNL program and future activities involving the first responder training template. One could envision an application where fundamental training (current classroom or template training) is given through a webinar followed by remote participation in in virtual reality scenarios.

Potential Impact: High 


\subsection{Existing Tools}

Recommendations for existing ESRTs are identified in section 2.3. The affected user groups and tickets associated with existing tools are found in Appendices E and F, respectively. Many of the tools need their content updated to remain relevant. The three online training tools also need a technology refresh to move away from outdated Adobe Flash to current HTML 5 format. Doing this will also make the content viewable on mobile platforms. Consolidating these tools to a single website would allow for information sharing across the tools.

\subsection{Recommendation Summary Tables}

The following tables summarize the recommendations for new and existing ESRTs that resulted from the planning session. Table 2 presents the recommendations for new tools and Table 3 presents recommendations for existing tools. 
Table 2. Recommendations for Implementation of New Tools

\begin{tabular}{|c|c|c|c|c|}
\hline ID\# & Title & $\begin{array}{l}\text { Affected User } \\
\text { Groups }\end{array}$ & Implementation Format & Comments \\
\hline \multicolumn{5}{|c|}{ High Impact Tools } \\
\hline GI-1 & Hydrogen Safety Portal & All & $\begin{array}{l}\text { Web site utilizing a content } \\
\text { management system (CMS) }\end{array}$ & $\begin{array}{l}\text { This tool could greatly impact all user groups by } \\
\text { providing credible and reliable information from a } \\
\text { trustworthy source. See Figure } 3 \text { for a mockup of the } \\
\text { portal. }\end{array}$ \\
\hline CS-1 & $\begin{array}{l}\text { Codes and Standards } \\
\text { Wizard/Guide }\end{array}$ & $\begin{array}{l}\text { AHJ,OM,PP, } \\
\text { RD,INS }\end{array}$ & $\begin{array}{l}\text { Custom relational database } \\
\text { driven web app }\end{array}$ & $\begin{array}{l}\text { This is a critical tool for supporting AHJ review and } \\
\text { approval. }\end{array}$ \\
\hline $\mathrm{NN}-1$ & $\begin{array}{l}\text { Scenario-Based Training for } \\
\text { First Responders }\end{array}$ & $\mathrm{FR} / \mathrm{SR}$ & $\begin{array}{l}\text { Virtual training system such as } \\
\text { vr-crisis.com }\end{array}$ & $\begin{array}{l}\text { This could be a 3D simulation platform aimed at } \\
\text { teaching, training and qualifying response units for } \\
\text { increased preparedness for risk and emergency } \\
\text { handling. This type of simulator could address the } \\
\text { training needs for individuals or teams, scaling the } \\
\text { command ladder from first response operators to } \\
\text { strategic command personnel. It allows for a wide } \\
\text { application of scenarios (vehicles, stationary apps, } \\
\text { transportation, maritime, etc.). }\end{array}$ \\
\hline NW-1 & Peer Networking & AHJ & Social network, forum, & Interactions with various user groups, feedback at the \\
\hline $\mathrm{NW}-2$ & & $\begin{array}{c}\text { AHJ } \\
\text { DD PD }\end{array}$ & knowledge base, etc. (examples - & planning session and general industry social movemen \\
\hline NW-3 & & $\mathrm{PP}, \mathrm{RD}$ & Twitter, Google+, LinkedIn, etc.) & $\begin{array}{l}\text { suggest great value in these types of tools. Connecting } \\
\text { inspectors and code officials also has the potential to } \\
\text { reduce delays in project approval due to lack of } \\
\text { experience. }\end{array}$ \\
\hline TR-2 & Training for Inspectors & AHJ & $\begin{array}{l}\text { Massive Open Online Course } \\
\text { (MOOC), Wiki, Videos, etc. }\end{array}$ & $\begin{array}{l}\text { This tool could provide an opportunity to help AHJ } \\
\text { reduce approval and permitting times. It could be } \\
\text { implemented through short instructional videos } \\
\text { incorporated into the portal and codes and standards } \\
\text { wizard. }\end{array}$ \\
\hline \multicolumn{5}{|c|}{ Medium Impact Tools } \\
\hline DR-2 & $\begin{array}{l}\text { Equipment and Project } \\
\text { Performance Data }\end{array}$ & OM,RD,INV,INS & $\begin{array}{l}\text { Searchable database available } \\
\text { through a web based resource }\end{array}$ & $\begin{array}{l}\text { These tools could have a significant impact but will take } \\
\text { much industry support and time to develop. Part of this } \\
\text { information is available through the NREL secure } \\
\text { database. }\end{array}$ \\
\hline IA-2 & Response Hotline & $\begin{array}{l}\mathrm{AHJ}, \mathrm{FR} / \mathrm{SR}, \mathrm{OM} \\
\mathrm{PP}, \mathrm{RD}\end{array}$ & $\begin{array}{l}\text { Telephone line and/or } \\
\text { social media }\end{array}$ & $\begin{array}{l}\text { This could require significant planning and resources to } \\
\text { plan and implement. }\end{array}$ \\
\hline
\end{tabular}




\begin{tabular}{|c|c|c|c|c|}
\hline ID\# & Title & $\begin{array}{l}\text { Affected User } \\
\text { Groups } \\
\end{array}$ & Implementation Format & Comments \\
\hline TR-1 & $\begin{array}{l}\text { Training for Maintenance and } \\
\text { Operations Personnel }\end{array}$ & $\mathrm{OM}$ & $\begin{array}{l}\text { Custom online course, } \\
\text { Wiki, Videos, etc. }\end{array}$ & $\begin{array}{l}\text { This tool could help reduce the number and severity of } \\
\text { potential events as OM personnel are unfamiliar with the } \\
\text { hazards of working with hydrogen. }\end{array}$ \\
\hline \multicolumn{5}{|c|}{ Low Impact Tools } \\
\hline GI-4 & General Safety Tools & All & $\begin{array}{l}\text { Web deployed Wikis, videos } \\
\text { and diagrams }\end{array}$ & $\begin{array}{l}\text { Some tools already exist including properties and } \\
\text { conversion calculators. Other areas such as answers to } \\
\text { general questions, pressure safety, flame arrestors, vent } \\
\text { systems, relief devices provide opportunity for further } \\
\text { development and should be developed as needs arise. }\end{array}$ \\
\hline \multicolumn{5}{|c|}{ Tools Already Under Development } \\
\hline DR-3 & Modeling/QRA Tools & AHJ,PP,D,INS & $\begin{array}{l}\text { Web and desktop tools which are } \\
\text { available through a DOE based } \\
\text { website by providing an API for } \\
\text { accessing these and creating a UI } \\
\text { and front-end to interface with the } \\
\text { underlying modeling code }\end{array}$ & $\begin{array}{l}\text { Tools are already under development by Sandia. They } \\
\text { should be integrated into the portal when completed. }\end{array}$ \\
\hline DR-5 & Risk Assessment Tools & AHJ,PP,INV,INS & Same as DR-3 & $\begin{array}{l}\text { Tools are already under development by Sandia. They } \\
\text { should be integrated into the portal when completed. }\end{array}$ \\
\hline CI-1 & $\begin{array}{l}\text { Third Party Certification } \\
\text { Guide }\end{array}$ & AHJ,PP & $\begin{array}{l}\text { Document available in Adobe } \\
\text { Acrobat format and available } \\
\text { through a website }\end{array}$ & $\begin{array}{l}\text { A task group from the Hydrogen Safety Panel is } \\
\text { developing the tool. It should be integrated into the } \\
\text { portal when completed. }\end{array}$ \\
\hline \multicolumn{5}{|c|}{ Tools Not Requiring Development by DOE } \\
\hline DR-1 & $\begin{array}{l}\text { Station Location and Design } \\
\text { Tools }\end{array}$ & PP,RD,INV & $\begin{array}{l}\text { A data driven web app with a } \\
\text { custom Google Maps frontend }\end{array}$ & $\begin{array}{l}\text { The group did not feel that there would be significant } \\
\text { impact from this tool and that they had enough resources } \\
\text { to address this need. }\end{array}$ \\
\hline GI-3 & $\begin{array}{l}\text { Vehicle and Equipment Safety } \\
\text { Information }\end{array}$ & AHJ,FR/SR,OM, INS & $\begin{array}{l}\text { Wiki, mobile app or web app } \\
\text { (a cross platform framework } \\
\text { such as Titanium would allow } \\
\text { for a write once, deploy } \\
\text { everywhere model) }\end{array}$ & $\begin{array}{l}\text { This information should be developed and deployed by } \\
\text { OEMs. H2USA could help ensure the necessary } \\
\text { information is made available. }\end{array}$ \\
\hline
\end{tabular}




\begin{tabular}{|c|c|c|c|c|}
\hline ID\# & Title & $\begin{array}{c}\text { Affected User } \\
\text { Groups } \\
\end{array}$ & Implementation Format & Comments \\
\hline OS-1 & On-scene Vehicle Information & FR/SR & Same as GI-3 & $\begin{array}{l}\text { OEMs should work with secondary responders to identify } \\
\text { needs and develop the appropriate tools. }\end{array}$ \\
\hline CI-2 & $\begin{array}{l}\text { List of Listed or Approved } \\
\text { Equipment }\end{array}$ & AHJ,PP,INS & Database-driven web app & $\begin{array}{l}\text { Very few listed components and systems are available } \\
\text { due to the relative immaturity of the industry. When } \\
\text { listed equipment becomes available, the testing } \\
\text { laboratories would be the best resource to make the } \\
\text { listing databases available. Until then, pursuing the third } \\
\text { party certification guide discussed in CI- } 2 \text { is a good } \\
\text { alternative. }\end{array}$ \\
\hline
\end{tabular}

Table 3. Recommendations for Existing Electronic Safety Resource Tools

\begin{tabular}{|c|c|c|c|c|c|c|}
\hline ID\# & Title & $\begin{array}{l}\text { Affected User } \\
\quad \text { Groups }\end{array}$ & $\begin{array}{l}\text { Update } \\
\text { Needed }\end{array}$ & Recommendations & $\begin{array}{l}\text { Include in } \\
\text { Portal? }\end{array}$ & $\begin{array}{l}\text { Portal Inclusion } \\
\text { Method }\end{array}$ \\
\hline EX-1 & $\begin{array}{l}\text { Introduction to } \\
\text { Hydrogen Safety for } \\
\text { First Responders }\end{array}$ & $\mathrm{FR} / \mathrm{SR}$ & Yes & $\begin{array}{l}\text { The current tool requires an update to convert it } \\
\text { from Adobe Flash to HTML5. Some content } \\
\text { may also require updating. }\end{array}$ & Yes & Embed \\
\hline EX-2 & $\begin{array}{l}\text { Hydrogen Incident } \\
\text { Reporting and Lessons } \\
\text { Learned Database }\end{array}$ & $\begin{array}{l}\text { AHJ,OM,PP,RD, } \\
\text { INV,PUB,INS }\end{array}$ & Yes & $\begin{array}{l}\text { Update for name/URL change to hydrogen } \\
\text { lessons learned. There may also be benefit in } \\
\text { connecting with the NFIRS folks to talk about } \\
\text { how to get the word hydrogen added to that } \\
\text { reporting system. }\end{array}$ & Yes & Embed \\
\hline EX-3 & $\begin{array}{l}\text { Hydrogen Safety Best } \\
\text { Practices }\end{array}$ & $\begin{array}{l}\text { AHJ,OM,PP,RD, } \\
\text { INV,PUB,INS }\end{array}$ & No & $\begin{array}{l}\text { Consider converting to database-driven content } \\
\text { for future usability. }\end{array}$ & Yes & Embed \\
\hline EX-4 & $\begin{array}{l}\text { Hydrogen Analysis } \\
\text { Resource Center } \\
\text { (HARC): Hydrogen } \\
\text { Conversion Calculator }\end{array}$ & $\begin{array}{l}\text { AHJ,FR/SROM, } \\
\text { PP,RD,PUB,INS }\end{array}$ & Maybe & $\begin{array}{l}\text { Evaluate for changes and a format change to } \\
\text { HTML5 and update as necessary. }\end{array}$ & Yes & Embed \\
\hline EX-5 & $\begin{array}{l}\text { Hydrogen Safety } \\
\text { Bibliographic } \\
\text { Database }\end{array}$ & AHJ,PP,RD & Yes & $\begin{array}{l}\text { New methods for farming bibliographic } \\
\text { hydrogen safety information should be explored. } \\
\text { One interface could be a binomial key style } \\
\text { wizard that interviews the user and drills down to } \\
\text { give recommendations or explanations. }\end{array}$ & Yes & API \\
\hline
\end{tabular}




\begin{tabular}{|c|c|c|c|c|c|c|}
\hline ID\# & Title & $\begin{array}{l}\text { Affected User } \\
\text { Groups }\end{array}$ & $\begin{array}{l}\text { Update } \\
\text { Needed }\end{array}$ & Recommendations & $\begin{array}{l}\text { Include in } \\
\text { Portal? }\end{array}$ & $\begin{array}{l}\text { Portal Inclusion } \\
\text { Method }\end{array}$ \\
\hline EX-6 & $\begin{array}{l}\text { HARC: Basic } \\
\text { Hydrogen Properties }\end{array}$ & All & Minor & $\begin{array}{l}\text { It may be beneficial to include additional } \\
\text { properties in this resource. }\end{array}$ & Yes & Embed \\
\hline $\mathrm{EX}-7$ & $\begin{array}{l}\text { Introduction to } \\
\text { Hydrogen for Code } \\
\text { Officials }\end{array}$ & AHJ & Yes & $\begin{array}{l}\text { The training information is outdated. Also } \\
\text { consider template approach similar to first } \\
\text { responder training so that this training could be } \\
\text { integrated at the USFA or fire department level. } \\
\text { Based on one of the tickets, the information } \\
\text { should be expanded to consider what is necessary } \\
\text { for review performance based designs } \\
\text { Additionally, the current tool requires an update } \\
\text { to convert it from Adobe Flash to HTML5. }\end{array}$ & Yes & Embed \\
\hline $\mathrm{EX}-8$ & $\begin{array}{l}\text { Regulators' Guide to } \\
\text { Permitting Hydrogen } \\
\text { Technologies }\end{array}$ & AHJ & ?? & $\begin{array}{l}\text { This resource is outdated and may no longer be } \\
\text { needed. Consider removing this resource. }\end{array}$ & No & N/A \\
\hline EX-9 & $\begin{array}{l}\text { Permitting Hydrogen } \\
\text { Facilities }\end{array}$ & AHJ,PP & Maybe & Evaluate for changes and update as necessary. & Yes & Embed \\
\hline EX-10 & $\begin{array}{l}\text { Hydrogen Tools IOS } \\
\text { App }\end{array}$ & AHJ,OM,PP,RD & Maybe & $\begin{array}{l}\text { The need for and function of the App should be } \\
\text { reevaluated after the portal is developed. }\end{array}$ & No & $\mathrm{N} / \mathrm{A}$ \\
\hline EX-11 & $\begin{array}{l}\text { Hydrogen Safety } \\
\text { Snapshot }\end{array}$ & AHJ,OM,PP,RD & Yes & $\begin{array}{l}\text { This resource is not current. Two tickets } \\
\text { indicated a desire to retain and update this tool. }\end{array}$ & Yes & Embed \\
\hline $\mathrm{EX}-12$ & $\begin{array}{l}\text { Technical Reference } \\
\text { for Hydrogen } \\
\text { Compatibility of } \\
\text { Materials }\end{array}$ & $\begin{array}{l}\text { AHJ,OM,PP,RD } \\
\text { INV,INS }\end{array}$ & No & Results need to be simplified for non-expert users & Yes & API \\
\hline EX-13 & $\begin{array}{l}\text { Hydrogen/Fuel Cell } \\
\text { Codes and Standards }\end{array}$ & $\begin{array}{l}\text { AHJ,OM,PP } \\
\text { INV,INS }\end{array}$ & N/A & Not a DOE Resource & No & N/A \\
\hline EX-14 & $\begin{array}{l}\text { Regulations, Codes, } \\
\text { and Standards } \\
\text { Template for } \\
\text { California Hydrogen } \\
\text { Dispensing Stations }\end{array}$ & AHJ,PP,INV & Maybe & $\begin{array}{l}\text { May need updating as new version of codes and } \\
\text { standards are adopted. This could also be } \\
\text { updated for more states. }\end{array}$ & Yes & Link \\
\hline
\end{tabular}




\begin{tabular}{|c|c|c|c|c|c|c|}
\hline ID\# & Title & $\begin{array}{l}\text { Affected User } \\
\text { Groups }\end{array}$ & $\begin{array}{l}\text { Update } \\
\text { Needed }\end{array}$ & Recommendations & $\begin{array}{l}\text { Include in } \\
\text { Portal? }\end{array}$ & $\begin{array}{l}\text { Portal Inclusion } \\
\text { Method }\end{array}$ \\
\hline EX-15 & $\begin{array}{l}\text { Hydrogen Safety } \\
\text { Training for } \\
\text { Researchers }\end{array}$ & $\mathrm{RD}$ & Yes & $\begin{array}{l}\text { The current tool requires an update to convert it } \\
\text { from Adobe Flash to HTML5. }\end{array}$ & Yes & Embed \\
\hline EX-16 & $\begin{array}{l}\text { Hydrogen Safety Tips } \\
\text { for First Responders }\end{array}$ & $\mathrm{FR} / \mathrm{SR}$ & $? ?$ & DOE resource? & Yes & Link \\
\hline EX-17 & $\begin{array}{l}\text { Hydrogen Safety Fact } \\
\text { Sheet (NHA) }\end{array}$ & All & N/A & Not a DOE resource. & Yes & Link \\
\hline EX-18 & $\begin{array}{l}\text { National Template: } \\
\text { Hydrogen Vehicle and } \\
\text { Infrastructure Codes } \\
\text { and Standards }\end{array}$ & AHJ,PP,INV,INS & No & & Yes & Link \\
\hline EX-19 & $\begin{array}{l}\text { Hydrogen Vehicle and } \\
\text { Infrastructure Codes } \\
\text { and Standards } \\
\text { Citations }\end{array}$ & AHJ,OM,PP,INS & No & & Yes & Link \\
\hline EX-20 & $\begin{array}{l}\text { Reaching the U.S. Fire } \\
\text { Service with } \\
\text { Hydrogen Safety } \\
\text { Information: A } \\
\text { Roadmap }\end{array}$ & AHJ,FR/SR & N/A & Not a DOE resource & Yes & Link \\
\hline EX-21 & $\begin{array}{l}\text { Hydrogen and Fuel } \\
\text { Cell Safety }\end{array}$ & AHJ & No & & Yes & Link or API \\
\hline
\end{tabular}




\subsection{Future Activities}

A small group of attendees from the planning session agreed to participate as an advisory group in future activities and the development of new tools. This group is identified in Appendix B (noted with an asterisk). They should be engaged through the design and development process as appropriate.

The planning session proved valuable for identifying opportunities to enhance the dissemination of safety knowledge. It was also valuable at connecting a number of different user groups together at one location/time to enable discussion on other non-session topics. Consideration should be given for future sessions at a two- or three-year frequency.

\subsection{References}

DOE. 2013. Fuel Cell Technologies Office Multi-Year Research, Development, and Demonstration Plan. July 2013. U.S. Department of Energy, Office of Energy Efficiency and Renewable Energy, Washington, D.C. 


\section{Appendix A}

\section{Existing Hydrogen and Fuel Cell Safety Electronic Resources}




\section{Appendix A}

\section{Existing Hydrogen and Fuel Cell Safety Electronic Resources}

Notes: Resources such as NFPA 2/853, safetygrams, and material safety data sheets are shown as examples, recognizing that other codes and standards organizations (e.g., CGA, ICC, SAE, CSA, ASME) and industrial gas suppliers also develop and provide similar resources.

\begin{tabular}{|c|c|c|c|}
\hline Resource by Category & \multicolumn{3}{|c|}{ DOE-funded } \\
\hline \multicolumn{4}{|c|}{ Databases/Websites (Including Regulations, C\&S) } \\
\hline $\begin{array}{l}\text { Hydrogen Incident Reporting and } \\
\text { Lessons Learned Database }\end{array}$ & http://www.h2incidents.org/ & $\bar{Y}$ & October 31,2013 \\
\hline $\begin{array}{l}\text { Hydrogen Safety Bibliographic } \\
\text { Database }\end{array}$ & $\begin{array}{l}\text { http://www.hydrogen.energy.gov/bibli } \\
\text { o database.html }\end{array}$ & Y & August 2008 \\
\hline $\begin{array}{l}\text { Hydrogen/Fuel Cell Codes and } \\
\text { Standards }\end{array}$ & http://www.fuelcellstandards.com/ & $\mathrm{N}$ & \\
\hline Hydrogen and Fuel Cell Safety & $\begin{array}{l}\text { http://www.hydrogenandfuelcellsafety. } \\
\text { info/ }\end{array}$ & Y & \\
\hline $\begin{array}{l}29 \text { CFR } 1910.103 \text { Occupational } \\
\text { Safety and Health Standards } \\
\text { (Hydrogen) }\end{array}$ & $\begin{array}{l}\text { https://www.osha.gov/pls/oshaweb/ow } \\
\text { adisp.show document?p table=STAN } \\
\text { DARDS\&p id=9749 }\end{array}$ & $\mathrm{N}$ & \\
\hline $\begin{array}{l}\text { Storage and Handling of Gaseous } \\
\text { and Liquefied Hydrogen }\end{array}$ & $\begin{array}{l}\text { http://www.michigan.gov/lara/0,4601, } \\
\text { 7-154-3529942271 4115 4237- } \\
\text { 193832--,00.html }\end{array}$ & $\mathrm{N}$ & \\
\hline $\begin{array}{l}\text { International Fire Code \& } \\
\text { International Building Code }\end{array}$ & $\begin{array}{l}\text { http://www.iccsafe.org/Pages/defau } \\
\text { lt.aspx }\end{array}$ & $\mathrm{N}$ & 2015 \\
\hline NFPA 1: Fire Code & $\begin{array}{l}\overline{\mathrm{http}: / / \mathrm{w} w w . n f p a . o r g / \text { codes-and- }} \\
\text { standards/document-information- } \\
\text { pages?mode }=\text { code } \& \text { code }=1\end{array}$ & $\mathrm{~N}$ & 2015 \\
\hline $\begin{array}{l}\text { NFPA 2: Hydrogen Technologies } \\
\text { Code }\end{array}$ & http://www.nfpa.org/2 & $\mathrm{N}$ & 2011 \\
\hline $\begin{array}{l}\text { NFPA 853: Standard for the } \\
\text { Installation of Stationary Fuel Cell } \\
\text { Power Systems }\end{array}$ & http://www.nfpa.org/853 & $\mathrm{N}$ & 2010 \\
\hline \multicolumn{4}{|c|}{ Manuals } \\
\hline Hydrogen Safety Best Practices & http://h2bestpractices.org/ & $\mathrm{Y}$ & April 18, 2013 \\
\hline $\begin{array}{l}\text { Technical Reference for Hydrogen } \\
\text { Compatibility of Materials }\end{array}$ & http://www.sandia.gov/matlsTechRef/ & Y & May 13,2013 \\
\hline $\begin{array}{l}\text { ANSI/AIAA G-095 - Guide to } \\
\text { Safety of Hydrogen and Hydrogen } \\
\text { Systems }\end{array}$ & $\begin{array}{l}\text { http://www.aiaa.org/StandardsDetail.as } \\
\text { px?id=3864 [US } \$ 100.95]\end{array}$ & $\mathrm{N}$ & 2004 \\
\hline $\begin{array}{l}\text { ISO/TR } 15916 \text { - Basic } \\
\text { considerations for the safety of } \\
\text { hydrogen systems }\end{array}$ & $\frac{\text { http://www.iso.org/iso/catalogue detai }}{1 \text { csnumber=29145 [CHF 172,00] }}$ & $\mathrm{N}$ & 2004 \\
\hline $\begin{array}{l}\text { FM Global Property Loss } \\
\text { prevention Data Sheets }\end{array}$ & $\frac{\text { http://www.fmglobal.com/FMGlobalR }}{\text { egistration/Vshared/FMDS0791.pdf }}$ & $\mathrm{N}$ & January 2012 \\
\hline
\end{tabular}




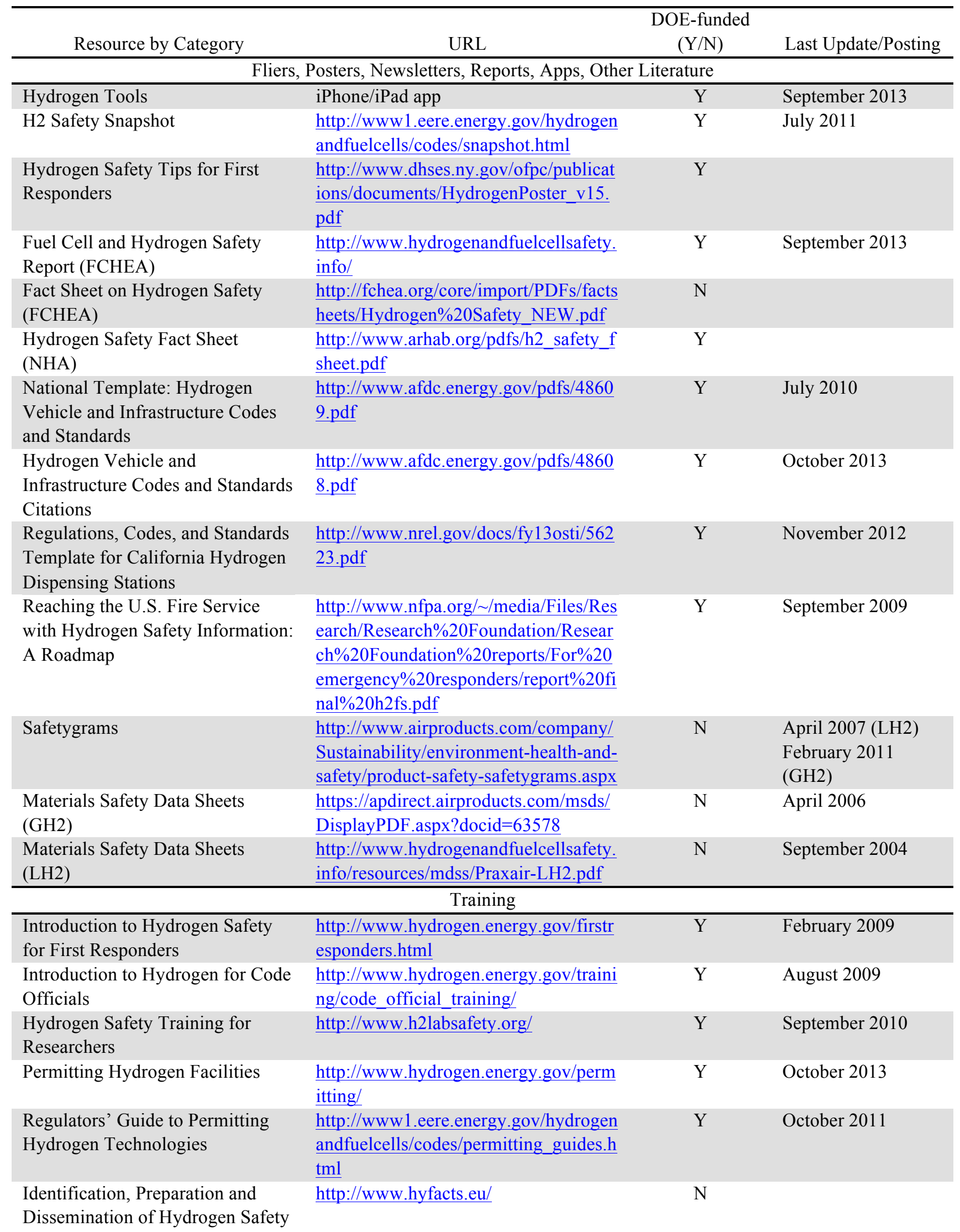




\begin{tabular}{llcl}
\hline \multicolumn{1}{c}{ Resource by Category } & \multicolumn{1}{c}{ URL } & $\begin{array}{c}\text { DOE-funded } \\
\text { (Y/N) }\end{array}$ & Last Update/Posting \\
\hline $\begin{array}{l}\text { Facts to Regulators and Public } \\
\text { Safety Officials (HyFACTS) }\end{array}$ & \multicolumn{1}{c}{ Properties, Calculators } & & \\
IAFF HazMat/WMD Training & http://www.iaff.org/et/HW/index.htm & $\mathrm{N}$ & \\
\hline $\begin{array}{l}\text { Hydrogen Analysis Resource } \\
\begin{array}{l}\text { Center (HARC): Basic Hydrogen } \\
\text { Properties }\end{array}\end{array}$ & $\begin{array}{l}\text { http://hydrogen.pnl.gov/cocoon/morf/h } \\
\text { yAdrogen/article/701 }\end{array}$ & $\mathrm{Y}$ & July 2008 \\
$\begin{array}{l}\text { HARC: Hydrogen Conversions } \\
\text { Calculator }\end{array}$ & $\begin{array}{l}\text { http://hydrogen.pnl.gov/cocoon/morf/h } \\
\text { ydrogen/site_specific/hydrogen_calcul } \\
\text { ator?canprint=false. }\end{array}$ & $\mathrm{Y}$ & January 2012 \\
\hline
\end{tabular}




\section{Appendix B}

\section{Electronic Safety Resources Planning Session Attendees}




\section{Appendix B}

\section{Electronic Safety Resources Planning Session Attendees}

Date: April 1, 2014

Location: Santa Fe Springs, CA Fire Department

\begin{tabular}{|c|c|c|c|}
\hline Name & Affiliation & Email & Telephone \\
\hline Nick Barilo & PNNL & nick.barilo@pnnl.gov & $509 / 371-7894$ \\
\hline Dave Farese & Air Products & faresedj@apci.com & $610 / 481-4869$ \\
\hline Aaron Harris & Air Liquide & aaron.harris@airliquide.com & $713 / 385-3939$ \\
\hline Tim Martin & FS Studio & tim@,fsstudio.com & $510 / 798-6392$ \\
\hline Carl Rivkin & NREL & carl.rivkin@nrel.gov & $303 / 275-3839$ \\
\hline Carl Baust & Orange Co. Fire & carlbaust@,ocfa.org & $949-724-6391$ \\
\hline Tim McGuire & MBZ/SAE & tim.mcguire@daimler.com & $916 / 340-4824$ \\
\hline Eric Binder* & Santa Monica Fire Department & eric.binder@ssmgov.net & $310 / 434-2666$ \\
\hline Richard Kallman* & $\begin{array}{l}\text { Santa Fe Springs Department } \\
\text { of Fire-Rescue }\end{array}$ & richardkallman@santafesprings.net & $562 / 906-3810$ \\
\hline Monte Elmore & PNNL & monte.elmore@pnnl.gov & $509 / 551-1602$ \\
\hline Will James & US DOE & charles.james@ee.doe.gov & $202 / 287-6223$ \\
\hline Jay Keller & H2USA & jay.keller@zces-inc.com & $925 / 519-2043$ \\
\hline Chris San Marchi & Sandia National Lab & cwsanma@sandia.gov & $925 / 294-4880$ \\
\hline Kym Carey & US DOE & kym.carey@ee.doe.gov & $202 / 287 / 1775$ \\
\hline Stephen Woods & NASA WSTF & stephen.s.woods@nasa.gov & $575 / 524-5607$ \\
\hline Miguel J. Maes* & NASA WSTF & miguel.j.maes@nasa.gov & $575 / 524-5677$ \\
\hline Joe Gagliano* & $\begin{array}{l}\text { California Fuel Cell } \\
\text { Partnership }\end{array}$ & jgagliano@cafcp.org & $714 / 393-2520$ \\
\hline Dan Poppe* & Hydrogen Frontier & dpoppe@hydrogenfrontier.com & $951 / 741-3631$ \\
\hline Kevin Reinertson* & $\begin{array}{l}\text { Office of the State } \\
\text { Fire Marshal }\end{array}$ & kevin.reinertson@fire.ca.gov & $916 / 327-4998$ \\
\hline Spencer Quong & QAI, representing Toyota & squong@squong.com & $415 / 230-0140$ \\
\hline Jeromy Markwort & PNNL & jeromy@pnl.gov & $509 / 948-0250$ \\
\hline
\end{tabular}

*Advisory group member 
Appendix C

Final Binning of Tickets 


\section{Appendix C}

\section{Final Binning of Tickets}

\begin{tabular}{|c|c|c|}
\hline ID No. & Functionality & Tickets \\
\hline OS-1 & $\begin{array}{l}\text { Provide critical safety } \\
\text { information to firefighters and } \\
\text { secondary responders (tow and } \\
\text { wrecking) when responding to } \\
\text { an event, includes VIN } \\
\text { scanning }\end{array}$ & $\begin{array}{ll}\text { - } & \text { VIN scanning app - disposition of vehicle/out points (UNGRP) } \\
\text { - As a FR/SR: I need: critical safety information on vehicles and } \\
\text { infrastructure when I am responding to an incident so I can } \\
\text { safely identify hazards and mitigate incident (FR) } \\
\text { - } \quad \text { on-scene response guide (FR) } \\
\text { - } & \text { Vehicle ID (FR) } \\
\text { Response guide (FR) }\end{array}$ \\
\hline NW-1 & $\begin{array}{l}\text { Facilitate networking among } \\
\text { AHJs }\end{array}$ & $\begin{array}{l}\text { - Email listserver user groups - 1 Los Angeles area Fire Marshals, } \\
2 \text { Southern CA Fire Prev officers, } 3 \text { Northern CA Fire Prev } \\
\text { officers, 4 CA Building Officials (UNGRP) } \\
\text { - List server discussion on H2 safety issues (UNGRP) } \\
\text { - AHJ - Network tools to allow various groups to connect (AHJ) } \\
\text { - Network of contacts for information (AHJ) }\end{array}$ \\
\hline NW-2 & $\begin{array}{l}\text { Facilitate networking among } \\
\text { inspectors }\end{array}$ & $\begin{array}{l}\text { Independent source to support AHJ as they have questions and } \\
\text { looking for previous systems and installations (AHJ) } \\
\text { Network for inspectors who have inspected with permit an H2 } \\
\text { system in their jurisdiction (AHJ) }\end{array}$ \\
\hline NW-3 & $\begin{array}{l}\text { Facilitate networking among } \\
\text { researchers and OEMs, station } \\
\text { builders, etc. }\end{array}$ & $\begin{array}{l}\text { - Network with auto OEMs, stations, builders, etc. to combine } \\
\text { resources (reduce redundancy) (RD) }\end{array}$ \\
\hline NW-4 & $\begin{array}{l}\text { Consult with independent } \\
\text { experts }\end{array}$ & $\begin{array}{ll}\text { - } & \text { Send out H2safety.ee.doe.gov address (UNGRP) } \\
\text { - } & \text { AHJs - utilize the panel? (UNGRP) } \\
\text { - } & \text { Insurers - task force to develop and work with insurers (INS) }\end{array}$ \\
\hline TR-1 & $\begin{array}{l}\text { Operations and maintenance } \\
\text { personnel need training on } \\
\text { hazards and operating } \\
\text { equipment that can provide } \\
\text { certification }\end{array}$ & $\begin{array}{l}\text { - Guidance on how to approach hazards in OM activities }(\mathrm{OM}) \\
\text { Provides station owners and operators a level of education to } \\
\text { functionally operate the station through a possible certification } \\
\text { process similar to USTs }(\mathrm{OM}) \\
\text { - Operations and maintenance (car manufacturers, dealers, service } \\
\text { stations, service personnel) education and understanding }(\mathrm{OM}) \\
\text { - Operations - general training program for maintenance repair } \\
\text { garages }(\mathrm{OM})\end{array}$ \\
\hline TR-2 & $\begin{array}{l}\text { Inspectors (AHJ) need } \\
\text { education and training }\end{array}$ & $\begin{array}{l}\text { - } \quad \text { Education tools for inspectors (AHJ) } \\
\text { - Inspector Training (UNGRP) }\end{array}$ \\
\hline NN-1 & $\begin{array}{l}\text { Scenario-based training for first } \\
\text { responders }\end{array}$ & $\begin{array}{l}\text { - Hands on experience (FR) } \\
\text { - } \quad \text { Avent scenarios (FR) } \\
\text { response when I need training cert. so that I can enhance my } \\
\text { basic training through real-life, scenario-based training and } \\
\text { respond appropriately and safely to hydrogen emergencies (FR) } \\
\text { - Remove mystery of H2 fuel and hydrogen firefighting to boots } \\
\text { on the ground. Demo and application (FR) } \\
\text { Quickly identify when H2 fires are occurring (FR) }\end{array}$ \\
\hline
\end{tabular}




\begin{tabular}{|c|c|c|}
\hline ID No. & Functionality & Tickets \\
\hline CS-1 & $\begin{array}{l}\text { A clear overview of applicable } \\
\text { codes and standards using }\end{array}$ & 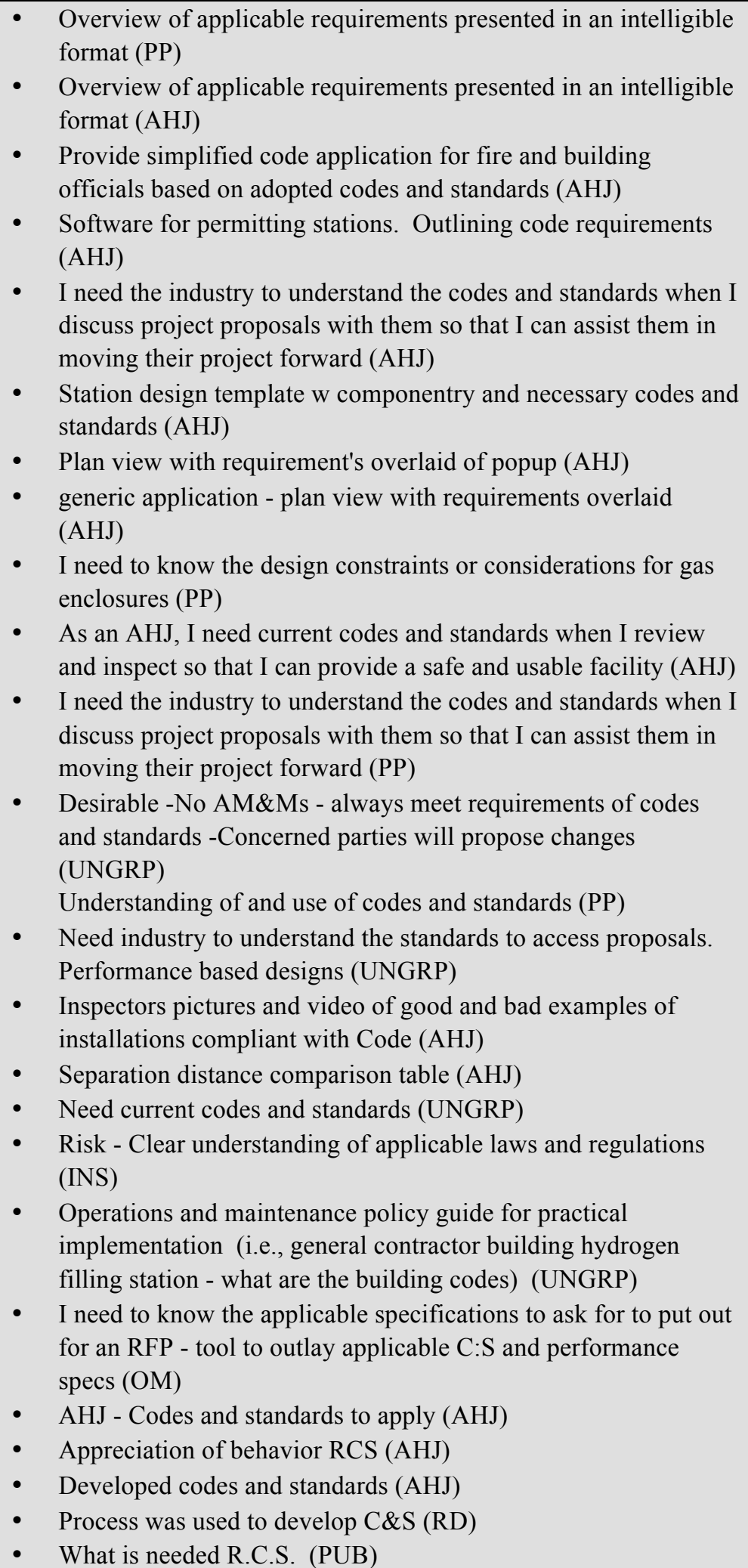 \\
\hline
\end{tabular}




\begin{tabular}{|c|c|c|}
\hline ID No. & Functionality & Tickets \\
\hline DR-1 & $\begin{array}{l}\text { Design tools to help identify } \\
\text { station locations (mapping), } \\
\text { options for station } \\
\text { configurations, standardized } \\
\text { plan formats, and identify } \\
\text { obstacles to project } \\
\text { deployments }\end{array}$ & $\begin{array}{l}\text { PP: I am a BizDev planner. I need a tool when I am identifying } \\
\text { locations for H2 fuel. So that I can Biz models and adjust } \\
\text { master plans (INV) } \\
\text { PP: I am a BizDev planner. I need a tool when I am identifying } \\
\text { locations for H2 fuel. So that I can Biz models and adjust } \\
\text { master plans (PP) } \\
\text { - Future: What we would like to see: standardized plan formats } \\
\text { broken into details demonstrating compliance on referenced } \\
\text { sheets and details. (UNGRP) } \\
\text { - PP: As a fuel supply engineer, I need an approved and vetted } \\
\text { tool when I am putting in stations, H2 install. So that I can } \\
\text { increase options for station design (PP) } \\
\text { - GIS systems to allow planners to visualize locations and } \\
\text { implications (INV) } \\
\text { - Researchers - need understanding of obstacles to project } \\
\text { deployment (RD) } \\
\text { Public permits, govs office, reduce roadblocks (PUB) }\end{array}$ \\
\hline DR-2 & $\begin{array}{l}\text { Data on equipment and project } \\
\text { performance including failure } \\
\text { rate data, MTBF, incident data, } \\
\text { real-time system performance } \\
\text { and "denominator" information } \\
\text { for frequency of incidents }\end{array}$ & $\begin{array}{l}\text { - Denominator for frequency of incidents-\#incidents/\#demands } \\
\text { (INS) } \\
\text { Denominator for frequency of incidents-\#incidents/\#demands } \\
\text { (RD) } \\
\text { - Denominator for frequency of incidents-\#incidents/\#demands } \\
\text { (INV) } \\
\text { - Data on project performance (INV) } \\
\text { - Corp Risk Manager - big data/data fusion API service that } \\
\text { allows various stakeholders to report H2 incidents and provide } \\
\text { analysis (INS) } \\
\text { - } \text { Database of component evaluation MTBF (OM) } \\
\text { Insurers - need operational data incident info to develop H2 } \\
\text { insurance programs (INS) } \\
\text { - Station performance protocol and H2 quality verification (OM) } \\
\text { Real-time system status database (OM) } \\
\text { PR tool-big data/NLP to monitor H2 in public space and } \\
\text { assessing general positive or general behavior (OM) }\end{array}$ \\
\hline DR-3 & $\begin{array}{l}\text { Modeling tools to predict } \\
\text { consequences of cryogenic } \\
\text { releases, pv failure, cryogenic } \\
\text { to gas releases, gaseous } \\
\text { releases, BLEVEs, etc., to } \\
\text { support station layout and risk } \\
\text { informed changes to regulation, } \\
\text { codes and standards }\end{array}$ & $\begin{array}{ll}\text { - } & \text { Tool to predict extent of cryogenic releases (UNGRP) } \\
\text { - } & \text { Blast analysis, plume modeling (aloha trace) multiple hazards } \\
\text { analysis methods, materials database (SNL), prob. Risk } \\
\text { assessment (SNL), FMEAs (UNGRP) } \\
\text { - } \quad \text { QRA and risk tool for helping design layout of station (PP) } \\
\text { - } \quad \text { Pool to predict pv failure consequences (UNGRP) } \\
\text { - } & \text { Modeling cryo -> gaseous releases (RD) } \\
\text { - } & \text { Risk informed approach to code requirements (RD) } \\
\text { - } & \text { Mitigation should feed into code (UNGRP) } \\
\text { - } & \text { Tool to predict extent of gaseous release (UNGRP) } \\
\text { - } & \text { Tool to predict consequence of BLEVE (guide exclusive zone } \\
& \text { size) (UNGRP) }\end{array}$ \\
\hline
\end{tabular}




\begin{tabular}{|c|c|c|}
\hline ID No. & Functionality & Tickets \\
\hline DR-4 & $\begin{array}{l}\text { Design detonation/deflagration } \\
\text { arrestors }\end{array}$ & $\begin{array}{ll}- & \text { Tool to design detonation/deflagration arrestors (UNGRP) } \\
\text { - } & \text { Tools to design flame arrestors (UNGRP) }\end{array}$ \\
\hline DR-5 & $\begin{array}{l}\text { Enable the performance of risk } \\
\text { assessments and provide } \\
\text { options for risk mitigation, } \\
\text { support performance-based } \\
\text { analysis, include checklist } \\
\text { functionality for basic risk, } \\
\text { component databases, } \\
\text { calculators and cost-benefit } \\
\text { features }\end{array}$ & 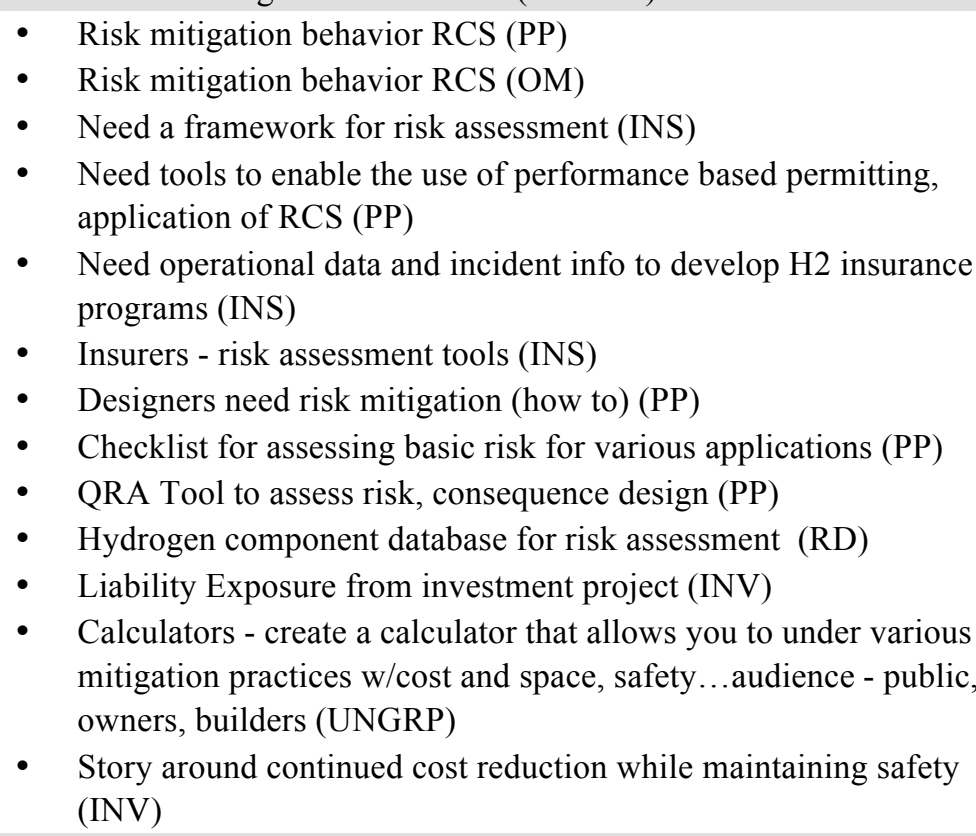 \\
\hline GI-1 & $\begin{array}{l}\text { Hydrogen safety portal as a } \\
\text { credible and reliable and one } \\
\text { stop shop for safety information }\end{array}$ & $\begin{array}{l}\text { - } \text { H2 safety portal (UNGRP) } \\
\text { - One stop shop website (UNGRP) } \\
\text { I am an Engineer and a C+S comm. I need results from a } \\
\text { trustworthy source when I am proposing code changes so that I } \\
\text { can win acceptance of my proposed changes (RD) } \\
\text { - Web Portal, a clearinghouse of all things H2 with links to } \\
\text { appropriate resources and sites. (UNGRP) } \\
\text { One stop shop reference about hydrogen (AHJ) }\end{array}$ \\
\hline GI-2 & $\begin{array}{l}\text { Public outreach utilizing } \\
\text { television, radio, internet, etc., } \\
\text { to address incidents, public } \\
\text { concerns and education as well } \\
\text { as provide detailed information } \\
\text { on vehicles and stations }\end{array}$ & $\begin{array}{l}\text { - } \quad \text { Nova" type prog? (UNGRP) } \\
\text { - } \quad \text { Get a Hollywood star to front? Jack? (UNGRP) } \\
\text { i.e. radio (PUB) } \\
\text { - } \quad \text { How to address public concerns (PUB) } \\
\text { - } \quad \text { Outreach and Education (PUB) } \\
\text { - } \quad \text { General public confidence, H2 is safe (PUB) } \\
\text { - } \quad \text { Videos for public to show its safe (UNGRP) } \\
\text { - } \quad \text { High pressure vehicles in use (PUB) } \\
\text { - } \text { firfrastructure locations; i.e. filling stations safety locations/the } \\
\text { - What is being done today? Not used for permitting in public. } \\
\quad \text { Used internally or was used to develop code SME reliance. (PP) }\end{array}$ \\
\hline
\end{tabular}




\begin{tabular}{|c|c|c|}
\hline ID No. & Functionality & Tickets \\
\hline GI-3 & $\begin{array}{l}\text { Vehicle and equipment } \\
\text { information covering general } \\
\text { information, safety features, } \\
\text { safe usage parameters, recall } \\
\text { notices, etc. }\end{array}$ & $\begin{array}{ll} & \text { Permit Officials - Need to understand properties of } \mathrm{H} 2 \text { and } \\
\text { - } & \text { Equipment to assess projects (AHJ) } \\
\text { - } & \text { Equipment definitions and safe usage parameters (AHJ) } \\
\text { - } & \text { Very generaipment definitions and safe usage parameters (FR) } \\
\text { - } & \text { How is this technology different in terms of safety (INS) } \\
\text { - } & \text { Need education of H2 cars to provide coverage (INS) } \\
\text { - } & \text { Retail Operators - need safety data on equip \& H2 to ensure safe } \\
\text { - operation (OM) } \\
\text { Need safety data on equipment and H2 to ensure safe operations } \\
\text { (OM) } \\
\text { Project proponents car manufactures; want a utility to indicate } \\
\text { safety info for FR, i.e., web service that provides updates for } \\
\text { recall notifications and recall info (PP) }\end{array}$ \\
\hline GI-4 & $\begin{array}{l}\text { General safety information on } \\
\text { properties of hydrogen and its } \\
\text { behavior, including a Wiki and } \\
\text { videos and diagrams showing } \\
\text { important safety features, } \\
\text { pressure safety, flame arrestors, } \\
\text { vent systems and relief devices }\end{array}$ & $\begin{array}{l}\text { - Permit Officials - Need to understand properties of H2 and } \\
\text { - } \text { Aquipment to assess projects (AHJ) } \\
\text { questions on hydrogen behavior so I can have access to } \\
\text { appropriate current info (FR) } \\
\text { - } \text { H2 Behavior (OM) } \\
\text { - Wiki (RD) } \\
\text { - Wiki (PP) } \\
\text { - Wiki (OM) } \\
\text { - Wiki (INV) } \\
\text { - Wiki (INS) } \\
\text { - Wiki (FR) } \\
\text { - Wiki (AHJ) } \\
\text { - } \text { Hideos and Diagrams showing important safety features (AHJ) } \\
\text { - As a FR I need internet resources (Wiki) when I have general } \\
\text { questions on hydrogen behavior so I can have access to } \\
\text { appropriate current info (FR) } \\
\text { - Pressure safety for compressible fluids (OM) } \\
\text { - Operations - Pressure safety of compressed fluids (OM) } \\
\text { Provide guides on specific topics, flame arrestors, vent systems, } \\
\text { relief devices, etc. (PP) }\end{array}$ \\
\hline CI-1 & $\begin{array}{l}\text { Guide for project certification } \\
\text { by third party based on a } \\
\text { tool/methodology that the AHJ } \\
\text { can trust, may include a } \\
\text { component certification } \\
\text { checklist }\end{array}$ & $\begin{array}{l}\text { - Component certification checklist (PP) } \\
\text { - } \text { Qualified 3rd party reviewers (AHJ) } \\
\text { - } \text { 3rd party vs fire dept expertise (AHJ) } \\
\text { - } \text { AHJ needs access to this tool to develop trust in the product } \\
\text { - } \quad \text { Guide for project certification (PP) }\end{array}$ \\
\hline
\end{tabular}




\begin{tabular}{|c|c|c|}
\hline ID No. & Functionality & Tickets \\
\hline CI-2 & $\begin{array}{l}\text { List of listed/approved } \\
\text { equipment and systems to } \\
\text { support review and approval of } \\
\text { designs }\end{array}$ & $\begin{array}{ll} & \text { Coded and labeled systems (PP) } \\
\text { - } & \text { List of tools/products from labs (UNGRP) } \\
\text { - } & \text { I need to know if this designed safely and appropriately without } \\
\text { prohibiting/penalizing design (AHJ) } \\
\text { - As an AHJ I need products that have been listed and approved } \\
\text { (By UL, FM) when I review and inspect so that I can approve } \\
\text { project more effectively (AHJ) } \\
\text { Meeting the code stay w/in the box keeping uniform and using } \\
\text { listed/approved products/design per standards or guidelines } \\
\text { (PUB) }\end{array}$ \\
\hline IA-1 & $\begin{array}{l}\text { Interactive tool to manage } \\
\text { public opinion and response }\end{array}$ & $\begin{array}{l}\text { Broad dissemination of information regarding the timely events. } \\
\text { i.e. radio (PUB) } \\
\text { - Outreach and Education (PUB) } \\
\text { - Monitor media and social media and respond with proactive } \\
\text { radio response team (UNGRP) }\end{array}$ \\
\hline IA-2 & $\begin{array}{l}\text { Hotlines for responding to } \\
\text { incidents and special issues }\end{array}$ & $\begin{array}{ll}\text { - } & \text { ERG Database and Hotline (FR) } \\
\text { - } & \text { Currently: Rely on SME to inform me (PP) } \\
\text { - } & \text { Database hotline (FR) } \\
\text { - } & \text { How to handle special issues (AHJ) } \\
\text { - } & \text { SME (RD) } \\
\text { - } & \text { Q\&A Hotline (AHJ) }\end{array}$ \\
\hline
\end{tabular}




\section{Appendix D}

\section{Affected User Groups for New Functional Tools}




\section{Appendix D}

\section{Affected User Groups for New Functional Tools}

\begin{tabular}{|c|c|c|c|c|c|c|c|c|c|}
\hline \multirow[b]{2}{*}{ ID \# } & \multirow[b]{2}{*}{ Functionality } & \multicolumn{8}{|c|}{ Affected User Groups } \\
\hline & & AHJ & $\mathrm{FR} / \mathrm{SR}$ & $\mathrm{OM}$ & $\mathrm{PP}$ & $\mathrm{RD}$ & $\mathrm{INV}$ & PUB & INS \\
\hline GI-4 & $\begin{array}{l}\text { General safety information on properties of } \\
\text { hydrogen and its behavior, including a Wiki and } \\
\text { videos and diagrams showing important safety } \\
\text { features, pressure safety, flame arrestors, vent } \\
\text { systems and relief devices }\end{array}$ & $\checkmark$ & $\checkmark$ & $\checkmark$ & $\checkmark$ & $\checkmark$ & $\checkmark$ & $\checkmark$ & $\checkmark$ \\
\hline GI-1 & $\begin{array}{l}\text { Hydrogen safety portal as a credible and reliable } \\
\text { and one stop shop for safety information }\end{array}$ & $\checkmark$ & $\checkmark$ & $\checkmark$ & $\checkmark$ & $\checkmark$ & $\checkmark$ & $\checkmark$ & $\checkmark$ \\
\hline CS-1 & $\begin{array}{l}\text { A clear overview of applicable codes and } \\
\text { standards using }\end{array}$ & $\checkmark$ & & $\checkmark$ & $\checkmark$ & $\checkmark$ & & & $\checkmark$ \\
\hline DR-3 & $\begin{array}{l}\text { Modeling tools to predict consequences of } \\
\text { cryogenic releases, pv failure, cryogenic to gas } \\
\text { releases, gaseous releases, BLEVEs, etc., to } \\
\text { support station layout and risk informed changes } \\
\text { to regulation, codes and standards }\end{array}$ & $\checkmark$ & & & $\checkmark$ & $\checkmark$ & & & $\checkmark$ \\
\hline DR-5 & $\begin{array}{l}\text { Enable the performance of risk assessments and } \\
\text { provide options for risk mitigation, support } \\
\text { performance-based analysis, include checklist } \\
\text { functionality for basic risk, component databases, } \\
\text { calculators and cost-benefit features }\end{array}$ & $\checkmark$ & & & $\checkmark$ & & $\checkmark$ & & $\checkmark$ \\
\hline IA-2 & $\begin{array}{l}\text { Hotlines for responding to incidents and special } \\
\text { issues }\end{array}$ & $\checkmark$ & $\checkmark$ & $\checkmark$ & $\checkmark$ & $\checkmark$ & & & \\
\hline NW-1 & Facilitate networking among AHJs & $\checkmark$ & & & & & & & \\
\hline NW-2 & Facilitate networking among inspectors & $\checkmark$ & & & & & & & \\
\hline $\mathrm{CI}-1$ & $\begin{array}{l}\text { Guide for project certification by third party } \\
\text { based on a tool/methodology that the AHJ can } \\
\text { trust, may include a component certification } \\
\text { checklist }\end{array}$ & $\checkmark$ & & & $\checkmark$ & & & & \\
\hline GI-3 & $\begin{array}{l}\text { Vehicle and equipment information covering } \\
\text { general information, safety features, safe usage } \\
\text { parameters, recall notices, etc. }\end{array}$ & $\checkmark$ & $\checkmark$ & $\checkmark$ & & & & & $\checkmark$ \\
\hline TR-2 & Inspectors $(\mathrm{AHJ})$ need education and training & $\checkmark$ & & & & & & & \\
\hline DR-2 & $\begin{array}{l}\text { Data on equipment and project performance } \\
\text { including failure rate data, MTBF, incident data, } \\
\text { real-time system performance and "denominator" } \\
\text { information for frequency of incidents }\end{array}$ & & & $\checkmark$ & & $\checkmark$ & $\checkmark$ & & $\checkmark$ \\
\hline OS-1 & $\begin{array}{l}\text { Provide critical safety information to firefighters } \\
\text { and secondary responders (tow and wrecking) } \\
\text { when responding to an event, includes VIN } \\
\text { scanning }\end{array}$ & & $\checkmark$ & & & & & & \\
\hline
\end{tabular}




\begin{tabular}{|c|c|c|c|c|c|c|c|c|c|}
\hline \multirow[b]{2}{*}{ ID \# } & \multirow[b]{2}{*}{ Functionality } & \multicolumn{8}{|c|}{ Affected User Groups } \\
\hline & & $\mathrm{AHJ}$ & $\mathrm{FR} / \mathrm{SR}$ & $\mathrm{OM}$ & PP & $\mathrm{RD}$ & INV & PUB & INS \\
\hline DR-1 & $\begin{array}{l}\text { Design tools to help identify station locations } \\
\text { (mapping), options for station configurations, } \\
\text { standardized plan formats, and identify obstacles } \\
\text { to project deployments }\end{array}$ & & & & $\checkmark$ & $\checkmark$ & $\checkmark$ & & \\
\hline $\mathrm{CI}-2$ & $\begin{array}{l}\text { List of listed/approved equipment and systems to } \\
\text { support review and approval of designs }\end{array}$ & $\checkmark$ & & & $\checkmark$ & & & & $\checkmark$ \\
\hline NW-3 & $\begin{array}{l}\text { Facilitate networking among researchers and } \\
\text { OEMs, station builders, etc. }\end{array}$ & & & & $\checkmark$ & $\checkmark$ & & & \\
\hline TR-1 & $\begin{array}{l}\text { Operations and maintenance personnel need } \\
\text { training on hazards and operating equipment that } \\
\text { can provide certification }\end{array}$ & & & $\checkmark$ & & & & & \\
\hline NN-1 & Scenario-based training for first responders & & $\checkmark$ & & & & & & \\
\hline $\mathrm{NW}-4 *$ & Consult with independent experts & $\checkmark$ & & & & & & & $\checkmark$ \\
\hline GI-2* & $\begin{array}{l}\text { Public outreach utilizing television, radio, } \\
\text { internet, etc., to address incidents, public } \\
\text { concerns and education as well as provide } \\
\text { detailed information on vehicles and stations }\end{array}$ & & & & & & & $\checkmark$ & \\
\hline IA- $1^{*}$ & $\begin{array}{l}\text { Interactive tool to manage public opinion and } \\
\text { response }\end{array}$ & & & & & & & $\checkmark$ & \\
\hline $\mathrm{DR}-4 *$ & Design detonation/deflagration arrestors & & & & $\checkmark$ & & & & \\
\hline
\end{tabular}




\section{Appendix E}

Affected User Groups for Existing Electronic Safety Resource Tools (DOE \& Non-DOE) 


\section{Appendix E}

\section{Affected User Groups for Existing Electronic Safety Resource Tools (DOE \& Non-DOE)}

\begin{tabular}{|c|c|c|c|c|c|c|c|c|c|c|c|}
\hline & \multicolumn{11}{|c|}{ Affected User Groups } \\
\hline ID \# & Title & AHJ & FR/SR & $\mathrm{OM}$ & PP & $\mathrm{RD}$ & INV & PUB & INS & $\begin{array}{c}\text { Last } \\
\text { Updated }\end{array}$ & $\begin{array}{c}\text { Needs } \\
\text { Updating? }\end{array}$ \\
\hline EX-17 & $\begin{array}{l}\text { Hydrogen Safety Fact } \\
\text { Sheet (NHA) }\end{array}$ & $\checkmark$ & $\checkmark$ & $\checkmark$ & $\checkmark$ & $\checkmark$ & $\checkmark$ & $\checkmark$ & $\checkmark$ & $?$ & No \\
\hline EX-6 & $\begin{array}{l}\text { HARC: Basic Hydrogen } \\
\text { Properties }\end{array}$ & $\checkmark$ & $\checkmark$ & $\checkmark$ & $\checkmark$ & $\checkmark$ & $\checkmark$ & $\checkmark$ & $\checkmark$ & 2008 & Maybe \\
\hline $\mathrm{EX}-2$ & $\begin{array}{l}\text { Hydrogen Incident } \\
\text { Reporting and Lessons } \\
\text { Learned Database }\end{array}$ & $\checkmark$ & & $\checkmark$ & $\checkmark$ & $\checkmark$ & $\checkmark$ & & $\checkmark$ & 2014 & Yes \\
\hline EX-4 & $\begin{array}{l}\text { Hydrogen Analysis } \\
\text { Resource Center } \\
\text { (HARC): Hydrogen } \\
\text { Conversion Calculator }\end{array}$ & $\checkmark$ & $\checkmark$ & $\checkmark$ & $\checkmark$ & $\checkmark$ & & $\checkmark$ & $\checkmark$ & 2012 & Maybe \\
\hline EX-3 & $\begin{array}{l}\text { Hydrogen Safety Best } \\
\text { Practices }\end{array}$ & $\checkmark$ & & $\checkmark$ & $\checkmark$ & $\checkmark$ & & $\checkmark$ & $\checkmark$ & 2013 & No \\
\hline $\mathrm{EX}-13$ & $\begin{array}{l}\text { Hydrogen/Fuel Cell } \\
\text { Codes and Standards }\end{array}$ & $\checkmark$ & & $\checkmark$ & $\checkmark$ & & $\checkmark$ & & $\checkmark$ & 2014 & \\
\hline EX-12 & $\begin{array}{l}\text { Technical Reference for } \\
\text { Hydrogen Compatibility } \\
\text { of Materials }\end{array}$ & $\checkmark$ & & $\checkmark$ & $\checkmark$ & $\checkmark$ & $\checkmark$ & & $\checkmark$ & 2013 & \\
\hline EX-19 & $\begin{array}{l}\text { Hydrogen Vehicle and } \\
\text { Infrastructure Codes and } \\
\text { Standards Citations }\end{array}$ & $\checkmark$ & & $\checkmark$ & $\checkmark$ & & & & $\checkmark$ & 2013 & No \\
\hline EX-5 & $\begin{array}{l}\text { Hydrogen Safety } \\
\text { Bibliographic Database }\end{array}$ & $\checkmark$ & & & $\checkmark$ & $\checkmark$ & & & & 2008 & Yes \\
\hline EX-18 & $\begin{array}{l}\text { National Template: } \\
\text { Hydrogen Vehicle and } \\
\text { Infrastructure Codes and } \\
\text { Standards }\end{array}$ & $\checkmark$ & & & $\checkmark$ & & $\checkmark$ & & $\checkmark$ & 2010 & Maybe \\
\hline EX-14 & $\begin{array}{l}\text { Regulations, Codes, and } \\
\text { Standards Template for } \\
\text { California Hydrogen } \\
\text { Dispensing Stations }\end{array}$ & $\checkmark$ & & & $\checkmark$ & & $\checkmark$ & & & 2012 & \\
\hline $\mathrm{EX}-10$ & $\begin{array}{l}\text { Hydrogen Tools IOS } \\
\text { App }\end{array}$ & $\checkmark$ & & $\checkmark$ & $\checkmark$ & $\checkmark$ & & & & 2014 & \\
\hline EX-16 & $\begin{array}{l}\text { Hydrogen Safety Tips } \\
\text { for First Responders }\end{array}$ & & $\checkmark$ & & & & & & & ? & No \\
\hline
\end{tabular}




\begin{tabular}{|c|c|c|c|c|c|c|c|c|c|c|c|}
\hline & \multicolumn{11}{|c|}{ Affected User Groups } \\
\hline ID \# & Title & AHJ & $\mathrm{FR} / \mathrm{SR}$ & $\mathrm{OM}$ & PP & RD & INV & PUB & INS & $\begin{array}{c}\text { Last } \\
\text { Updated }\end{array}$ & $\begin{array}{c}\text { Needs } \\
\text { Updating? }\end{array}$ \\
\hline EX-20 & $\begin{array}{l}\text { Reaching the U.S. Fire } \\
\text { Service with Hydrogen } \\
\text { Safety Information: A } \\
\text { Roadmap }\end{array}$ & $\checkmark$ & $\checkmark$ & & & & & & & 2010 & No \\
\hline EX-11 & $\begin{array}{l}\text { Hydrogen Safety } \\
\text { Snapshot }\end{array}$ & $\checkmark$ & & $\checkmark$ & $\checkmark$ & $\checkmark$ & & & & 2011 & \\
\hline EX-9 & $\begin{array}{l}\text { Permitting Hydrogen } \\
\text { Facilities }\end{array}$ & $\checkmark$ & & & $\checkmark$ & & & & & 2013 & \\
\hline EX-21 & $\begin{array}{l}\text { Hydrogen and Fuel Cell } \\
\text { Safety }\end{array}$ & $\checkmark$ & & & & & & & & 2014 & No \\
\hline EX-1 & $\begin{array}{l}\text { Introduction to } \\
\text { Hydrogen Safety for } \\
\text { First Responders }\end{array}$ & & $\checkmark$ & & & & & & & 2009 & Yes \\
\hline EX-15 & $\begin{array}{l}\text { Hydrogen Safety } \\
\text { Training for Researchers }\end{array}$ & & & & & $\checkmark$ & & & & 2010 & Yes \\
\hline EX-7 & $\begin{array}{l}\text { Introduction to } \\
\text { Hydrogen for Code } \\
\text { Officials }\end{array}$ & $\checkmark$ & & & & & & & & 2009 & Yes \\
\hline EX-8 & $\begin{array}{l}\text { Regulators' Guide to } \\
\text { Permitting Hydrogen } \\
\text { Technologies }\end{array}$ & $\checkmark$ & & & & & & & & 2011 & \\
\hline
\end{tabular}




\section{Appendix F}

\section{Tickets Associated with Existing Tools}




\section{Appendix F}

\section{Tickets Associated with Existing Tools}

\begin{tabular}{|c|c|c|}
\hline ID No. & Functionality & Tickets \\
\hline EX-1 & $\begin{array}{l}\text { Introduction to Hydrogen Safety for First } \\
\text { Responders }\end{array}$ & $\begin{array}{ll}\text { - } & \text { Uniform and current training (FR) } \\
\text { - } & \text { Quickly identify when H2 fires are occurring (FR) } \\
\text { (FR) } \\
\text { - } \quad \text { Up to date training as tech evolves (FR) } \\
\text { - Simple, easy to remember training on H2 safety } \\
\text { issues (FR) } \\
\text { - FR - Up-to-date training materials as technology } \\
\text { evolves (FR) } \\
\text { Event scenarios (FR) }\end{array}$ \\
\hline EX-2 & $\begin{array}{l}\text { Hydrogen Incident Reporting and Lessons } \\
\text { Learned Database }\end{array}$ & 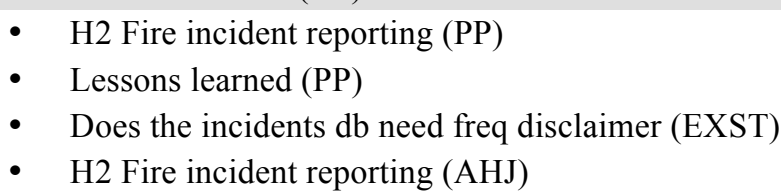 \\
\hline EX-3 & Hydrogen Safety Best Practices & - $\quad$ Best practices (INV) \\
\hline EX-4 & $\begin{array}{l}\text { Hydrogen Analysis Resource Center } \\
\text { (HARC): Hydrogen Conversion Calculator }\end{array}$ & $\begin{array}{l}\text { - Basic tools for } \mathrm{H} 2 \text { properties calculators etc. - all } \\
\text { audiences (PP) }\end{array}$ \\
\hline EX-5 & Hydrogen Safety Bibliographic Database & $\begin{array}{l}\text { - History of past R\&D efforts, easy access to info to } \\
\text { preserve institutional knowledge (RD) }\end{array}$ \\
\hline EX-6 & HARC: Basic Hydrogen Properties & $\begin{array}{l}\text { - Basic tools for } \mathrm{H} 2 \text { properties calculators etc. - all } \\
\text { audiences (PP) }\end{array}$ \\
\hline $\begin{array}{l}\text { EX-7 } \\
\text { EX-8 }\end{array}$ & $\begin{array}{l}\text { Introduction to Hydrogen for Code Officials } \\
\text { Regulators' Guide to Permitting Hydrogen } \\
\text { Technologies }\end{array}$ & $\begin{array}{l}\text { - Consistent training of hydrogen standards cross all } \\
\text { AHJs (to attempt standardization) (AHJ) } \\
\text { AHJ - Codes, standards, training, development } \\
\text { (AHJ) } \\
\text { - As an AHJ I need training for when I plan review } \\
\text { and inspect so that safety, uniformity, and reduced } \\
\text { cost (AHJ) } \\
\text { - Permit Officials - Need to understand properties of } \\
\text { H2 and Equipment to assess projects (AHJ) } \\
\text { AHJ - Understanding codes, consequence, } \\
\text { mitigation methods (AHJ) } \\
\text { I as an AHJ need to have trained and resources } \\
\text { when I address/review projects that are } \\
\text { performance base designs (AHJ) }\end{array}$ \\
\hline EX-9 & Permitting Hydrogen Facilities & None \\
\hline EX-10 & Hydrogen Tools IOS App & None \\
\hline EX-11 & Hydrogen Safety Snapshot & $\begin{array}{l}\text { - Tool: database/outreach with a monthly quarterly } \\
\text { newsletter like CCPS Beacon (UNGRP) } \\
\text { - Coffee break training - one page summary on all } \\
\text { topics (UNGRP) }\end{array}$ \\
\hline
\end{tabular}




\begin{tabular}{|c|c|c|}
\hline ID No. & Functionality & Tickets \\
\hline EX-12 & $\begin{array}{l}\text { Technical Reference for Hydrogen } \\
\text { Compatibility of Materials }\end{array}$ & None \\
\hline EX-13 & Hydrogen/Fuel Cell Codes and Standards & None \\
\hline EX-14 & $\begin{array}{l}\text { Regulations, Codes, and Standards } \\
\text { Template for California Hydrogen } \\
\text { Dispensing Stations }\end{array}$ & None \\
\hline EX-15 & Hydrogen Safety Training for Researchers & None \\
\hline EX-16 & Hydrogen Safety Tips for First Responders & None \\
\hline EX-17 & Hydrogen Safety Fact Sheet (NHA) & None \\
\hline EX-18 & $\begin{array}{l}\text { National Template: Hydrogen Vehicle and } \\
\text { Infrastructure Codes and Standards }\end{array}$ & None \\
\hline EX-19 & $\begin{array}{l}\text { Hydrogen Vehicle and Infrastructure Codes } \\
\text { and Standards Citations }\end{array}$ & None \\
\hline EX-20 & $\begin{array}{l}\text { Reaching the U.S. Fire Service with } \\
\text { Hydrogen Safety Information: A Roadmap }\end{array}$ & None \\
\hline EX-21 & Hydrogen and Fuel Cell Safety & None \\
\hline
\end{tabular}




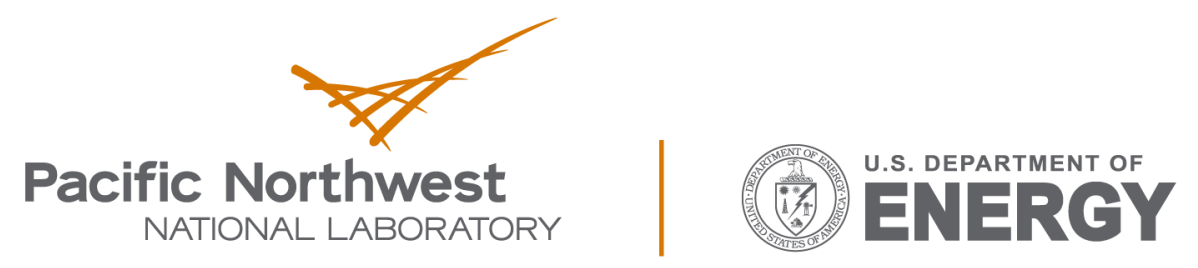

Proudly Operated by Battelle Since 1965

902 Battelle Boulevard

P.O. Box 999

Richland, WA 99352

1-888-375-PNNL (7665)

www.pnnl.gov 